\title{
Tanzania: Financial System Stability Assessment, including Reports on the Observance of Standards and Codes on Banking Supervision
}

This Financial System Stability Assessment on Tanzania was prepared by a staff team of the International Monetary Fund and the World Bank as background documentation for the periodic consultation with the member country. It is based on the information available at the time it was completed on July 10, 2003. The views expressed in this document are those of the staff team and do not necessarily reflect the views of the government of Tanzania or the Executive Board of the IMF.

The policy of publication of staff reports and other documents by the IMF allows for the deletion of market-sensitive information.

To assist the IMF in evaluating the publication policy, reader comments are invited and may be sent by e-mail to publicationpolicy@imf.org.

\author{
Copies of this report are available to the public from \\ International Monetary Fund $\bullet$ Publication Services \\ 700 19th Street, N.W. $\bullet$ Washington, D.C. 20431 \\ Telephone: (202) 6237430 • Telefax: (202) 6237201 \\ E-mail: publications@imf.org • Internet: http://www.imf.org
}

Price: $\$ 15.00$ a copy

\section{International Monetary Fund \\ Washington, D.C.}




\title{
INTERNATIONAL MONETARY FUND
}

\author{
TANZANIA
}

\section{Financial System Stability Assessment}

\section{Prepared by the Monetary and Financial Systems and the African Departments}

\author{
Approved by Stefan Ingves and Abdoulaye Bio-Tchané
}

July 10,2003

\begin{abstract}
The Financial System Stability Assessment (FSSA) is based on the work of the joint IMF-World Bank Financial Sector Assessment Program missions to Tanzania in May 2003. The mission met with senior government officials, including the govemor and staff of the central bank, officials of institutions and agencies involved in supervision and regulation of the financial system, banks, micro-finance institutions, insurance companies, securities firms, auditors, and other market participants. The mission work also included a field study based on focus groups of households and micro/small enterprises in urban and rural areas.
\end{abstract}

The FSAP team comprised Messrs. Patrick Honohan (World Bank, Mission Chief), Udaibir S. Das (IMF, Deputy Chief); Mmes. Shyamala Gopinath and Roxana Nikdjou (mission assistant); and Messrs. Stephen Swaray and Richard Podpiera (all IMF); Mmes. Nagavalli Annamalai and Claire Grose; Messrs. Carlos Cuevas, Xavier Gine, and Donald McIsaac (all World Bank); Messrs. Frederic Hervo (expert, Banque de France), and Geof Mortlock (expert, Reserve Bank of New Zealand). Mr. Meshack Tjirongo (IMF) and Ms. Susan Marcus (World Bank) assisted the mission in the field.

The banking system in Tanzania, which dominates the financial system, is liquid, well capitalized, and resilient to most shocks; however, it performs only a very limited role in the economy, even by Sub-Saharan Africa standards. Despite some indications of progress following the recent extensive policy reforms, the current depth and efficiency of the financial system fall well short of what is needed to help support economic growth. Credit to the private sector remains very small and mostly short-term. Interest rate spreads, though declining, are high, and banks accumulate extensive holdings of government paper and sizeable offshore dollar placements. Nonbank financial institutions have been growing but are still too small to be of much systemic concern.

The mission recommended a number of legal, judicial, and institutional reforms that would remove the main obstacles to lending, deepen financial intermediation and help develop the financial system, including the following: (i) reform of government-owned financial institutions; (ii) legal and judicial reforms; (iii) enhancing access to financial services, including the promotion of microfinance and the creation of credit registry; (iv) long-term investment by insurance companies and pension funds; (v) bank regulation and supervision; and (vii) crisis preparedness. The mission also recommended strengthening monetary management, including market intervention policies, transparency, and payment and securities settlement systems in light of the continuing strong aid inflows.

This report is divided into two parts. The first part provides a staff report on financial sector issues. The second part presents a summary assessment of compliance with Basel Core Principles for Effective Banking Supervision. The AML-CFT assessment for Tanzania is underway and a ROSC will be sent subsequently to the Board for its information.

The main authors of this report are Udaibir S. Das, Richard Podpiera, and Stephen Swaray. 
Part I. Staff Report on Financial Sector Issues .............................................................. 4

I. Overall Assessment of Stability and Development Issues ........................................ 4

II. Overview of the Financial System ………….................................................... 7

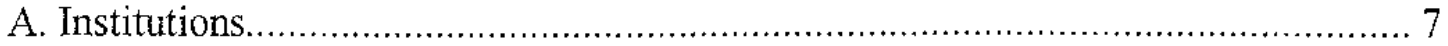

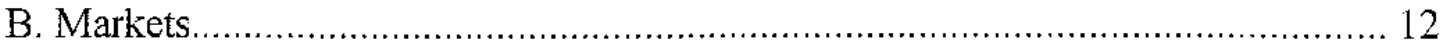

C. Recent Macroeconomic Developments ....................................................... 13

III. Vulnerabilities and Soundness of the Financial System ...................................... 13

A. Macroeconomic Sources of Risks to Financial Stability ................................... 13

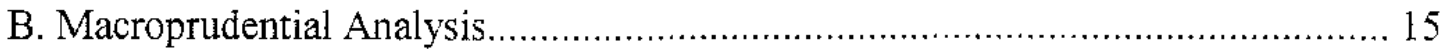

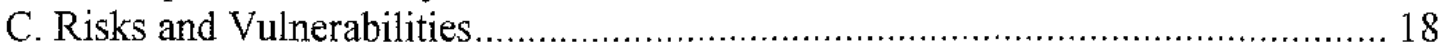

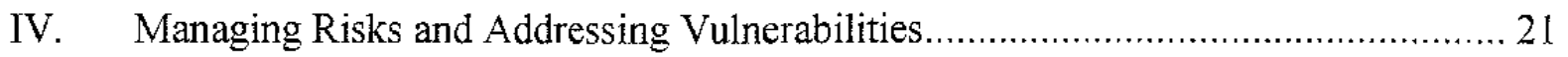

A. Prudential Regulation and Supervision .......................................................... 21

B. Management of Systemic Liquidity and Development of Financial Markets ....... 24

V. Improving the Effectiveness and Reach of the Financial Sector..............................28

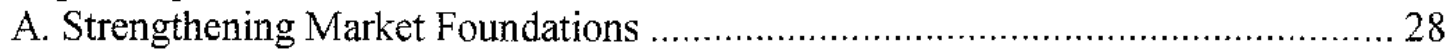

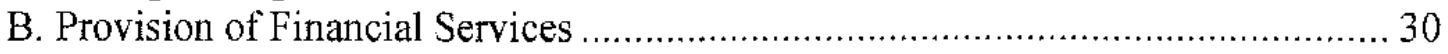

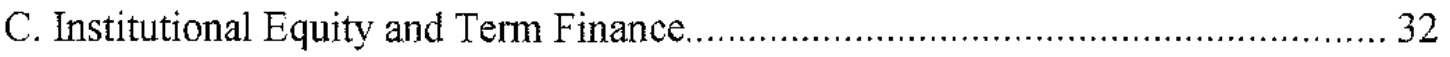

Part II. Observance of Financial Sector Standards and Codes: Summary Assessments ........ 34

I. Basel Core Principles for Effective Banking Supervision................................... 34

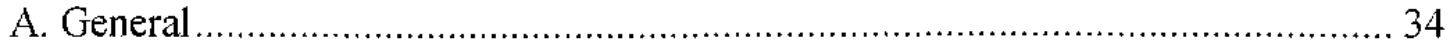

B. General Preconditions for Effective Banking Supervision................................... 35

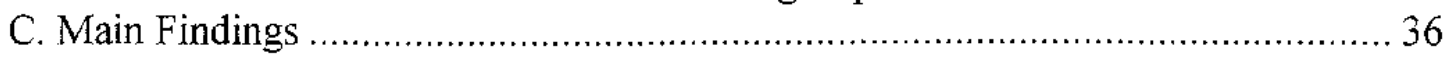

Text Tables

1. Main Recommended Actions to Improve Compliance with the Basel Core Principles . 39

Tables

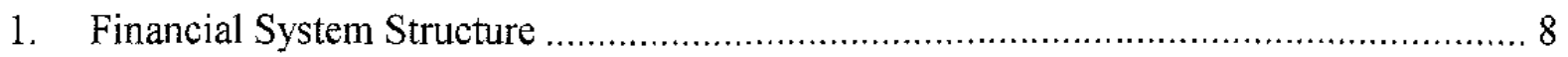

2. International Comparison of Selected Development Indicators ................................ 11

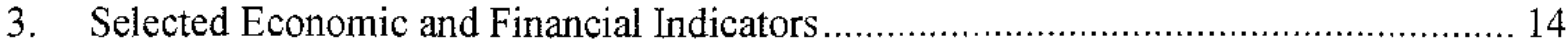

4. Financial Soundness Indicators for the Banking Sector .......................................... 16

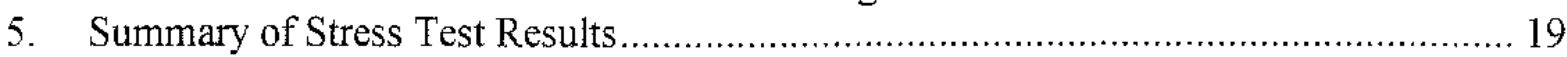

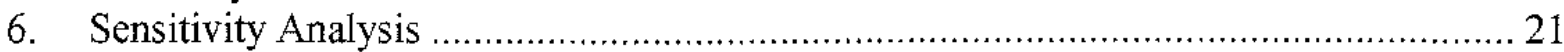

Boxes

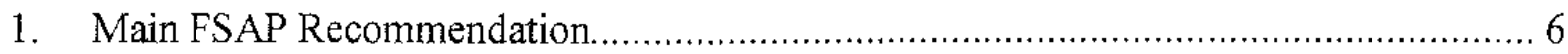

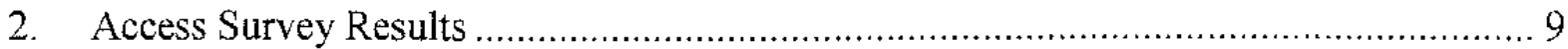

3. Functional Effectiveness of the Financial System .................................................. 10

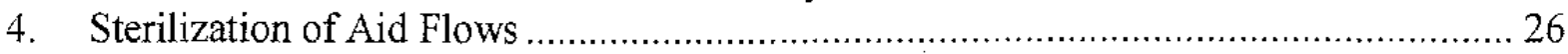




\section{GLOSSARY}

\begin{tabular}{|l|l|}
\hline BCP & Basel Core Principles \\
\hline BOT & Bank of Tanzania \\
\hline CAR & Capital adequacy ratio \\
\hline COMESA & Common Market for Eastern and Southern Africa \\
\hline CMSA & Capital Markets and Securities Authority \\
\hline CRDB & Cooperative and Rural Development Bank \\
\hline DBS & Directorate of Banking Supervision \\
\hline DIF & Deposit Insurance Fund \\
\hline DSE & Dar es Salaam Stock Exchange \\
\hline DvP & Delivery versus payment \\
\hline EAC & East African Community \\
\hline HBS & Household Budget Survey \\
\hline ISD & Insurance Supervision Department \\
\hline LOLR & Lender-of-last resort \\
\hline MFC & Microfinance companies \\
\hline MFI & Microfinance institution \\
\hline NBC & National Bank of Commerce \\
\hline NGO & Nongovernmental organization \\
\hline NIC & National Insurance Corporation \\
\hline NMB & National Microfinance Bank \\
\hline NPS & National Payment Systems \\
\hline NSSF & National Social Security Fund \\
\hline ODA & Official Development Assistance \\
\hline PBZ & People's Bank of Zanzibar \\
\hline PPF & Parastatal Pension Fund \\
\hline PRSP & Poverty Reduction Strategy Paper \\
\hline PvP & Payment versus payment \\
\hline RI & Regional integration \\
\hline RTGS & Real-time gross settlement \\
\hline SACA & Savings and Credit Association \\
\hline SACCO & Savings and Credit Cooperative \\
\hline SADC & Southern African Development Community \\
\hline SME & Small- and medium-sized enterprises \\
\hline TIB & Tanzania Investment Bank \\
\hline TPB & Tanzania Postal Bank \\
\hline & \\
\hline
\end{tabular}




\section{Part I. Staff Report on FInanclal Sector IsSues}

\section{Overall ASSESSMENT OF StaBility ANd DeVelopyent ISSUES}

1. The Tanzanian financial system plays a limited role in the economy and its current depth and efficiency fall well short of what is needed to help support economic growth. Extensive policy reforms have been put in place over the past few years, but these are yet to yield the expected dividends. There are indications of progress, including growth in lending and increased competition in microfinance. However, credit to private sector remains very small and mostly short-term, interest rate spreads are high, and banks accumulate extensive holdings of government paper and sizeable offshore dollar placements. Unfinished privatization, and, most of all, a number of structural impediments to lending, including poor credit culture, difficult and slow enforcement of creditor rights, and lack of suitable collateral are the main factors limiting financial intermediation.

2. Tanzania has enjoyed stable macroeconomic environment recently, but several macroeconomic risks exist. These arise mainly from the structure of the real economy and Tanzania's dependence on large and potentially volatile aid flows. The economy's dependence on agriculture leaves Tanzania highly vulnerable to external shocks-drought and falling world commodity prices. The economy is also vulnerable to a decline in tourism revenues, which is not unlikely given the current international security concerns. Major delays in aid disbursements and a sudden and sharp drop in aid inflows could expose the country to substantial internal and external imbalances.

3. Tanzanian banks, which dominate the country's financial system, are generally liquid, well capitalized, and resilient to most shocks according to the stress tests performed. The banking system boasts of a capital adequacy ratio in excess of 20 percent. Relatively low lending activity limits the extent of credit risk and the system would be able to endure sizeable shocks to credit quality. Concentration of lending is a cause for concern, but does not appear to pose an immediate risk. Regulatory limits on foreign exchange exposures as well as the cautious approach of banks to lending in foreign currency limit the consequences of even a large movement of the exchange rate. Similarly, banks would be able to endure a significant reduction of interest spread. The only major risk area is interest rate risk. Although the vast majority of lending is short-term, some banks have significant holdings of government bonds which expose them to considerable interest rate risk.

4. A distinctive feature of the financial environment in Tanzania is the high degree of liquidity. Availability of loanable funds is unlikely to be a constraining factor in the medium term. This is true for both long-term as well as short-term funds, given the growing investable resources of the pension funds and, to a lesser extent, the insurance companies. The availability of long-term resources for future investment in securitized medium- and long-term bank loans and corporate bonds, as well as the equities in which they now invest, is a source of strength for the system, but one which will only come to full realization when the banks have identified suitably bankable medium-term loan opportunities.

5. Monetary policy instruments are well developed and the Bank of Tanzania (BOT) has sufficient instruments at its disposal to cope with volatile aid inflows. In the short term, monetary policy will need to ensure that potential excess liquidity emanating 
from surging aid flows does not reignite inflation. At the same time, the BOT needs to avoid the opposing error of over-tightening policy if the demand for money shifts. An adaptive stance based on continuous analytical work in estimating the demand for money and responding to changing information will be necessary. The shallowness of wholesale money, bond and exchange markets continues to present challenges to monetary management. The BOT displays a sufficient high degree of transparency in its formulation and implementation of monetary policy, although some strengthening is required.

6. Other parts of the financial system are small and do not pose a systemic threat, as it appears unlikely at this point that difficulties in one of them would affect overall confidence in the financial sector. The performance and potential of the insurance sector, which was opened to entry as recently as 1998 , is overshadowed by the very poor condition of the former monopoly; rehabilitating it will be a difficult task. Although there is steady progress in the number of equity listings on the Dar es Salaam stock exchange (DSE), this cannot mask the fact that the operation of the exchange and its regulation still represent a drain on scarce public funds and are likely to do so for some time. Despite the prospect of some foreign portfolio investment following the welcome partial liberalization of equity purchases from abroad and of cross-listings, the exchange is likely to play a very limited role for several years to come.

7. The framework of banking supervision is generally adequate when assessed against the Basel Core Principles. Most important regulations are in line with international standards and provisioning rules are conservative. Improvements are needed in on-site supervision by graduating from checking compliance to an evaluation and management of risks. Supervision would also be strengthened by enhancing transparency of banking supervision policies and BOT's independence from the government with respect to revocation of licenses and instituting corrective action. Although no crisis is in prospect, contingency planning needs to be developed, and the use of lender-of-last resort (LOLR) facilities and the role of the deposit insurance clarified.

\section{Looking forward, there are strong reasons to expect that Tanzania's financial} sector will consolidate recent gains and play a more significant role in the economy, if supported by appropriate policies, and continuing structural reform. Recent expansion of credit, including by the international banks, both in aggregate terms and to a wider range of small-scale borrowers, is an important sign of improvement. Increasingly vigorous competition and availability of deposit resources point to the likelihood that banks will reach down further into serving smaller-scale clients. The stability offered by the thrust of the overall financial sector policy environment can underpin such gains. Continued strengthening of the credit environment and financial infrastructure - and completing the divestiture of state-controlled entities in banking and insurance-should guide Tanzania's financial sector policy in the coming years.

9. The FSAP recommended a number of legal, judicial, and institutional reforms that would remove the main obstacles to lending, deepen financial intermediation, and help develop the financial system. These include the following: (i) reform of governmentowned financial institutions, including finalization of the privatization process; (ii) legal and judicial reforms to remove main obstacles to lending; (iii) enhancing access to financial services, including the promotion of microfinance and the creation of credit registry; (iv) liberalization and development of long-term investment by insurance companies and pension funds; and (v) further improvements of bank regulation and supervision (Box 1 ). 


\section{Box 1. Main FSAP Recommendations 1/2/}

\section{Enhancing access to financial services}

- Clarify regulatory intentions regarding smaller microfinance institutions (MFIs).

- Encourage the development and strengthening of umbrella organizations and greater reliance by these MFIs on local banks rather than external donors.

- Consider an agency for cooperative financial institutions focusing on capacity building and financial infrastructure; seek donor funding for this type of initiative.

- The BOT should take the lead on the credit registry/bureau project and push ahead speedily with a simple—but if necessary compulsory - system of credit reporting by all licensed lenders.

- Clarify or amend regulations concerning the treatment of leasing companies.

- Abandon policy prescriptions to open special windows for small- and medium-sized enterprises (SMEs) at financial institutions or for government-promoted development banks.

- Develop a payment system infrastructure to facilitate retail payments.

\section{Reform of government-owned financial institutions}

- Move promptly to sell a substantial majority stake in NMB to a suitably qualified foreign buyer.

- Initiate privatization of Tanzania Investment Bark (TIB); pending privatization, limit its loan portfolio, and transform TPB into a narrow bank.

- Restore public confidence in the insurance market as soon as possible through finding a buyer for the National Insurance Corporation (NIC); failing which, close the NIC to new business and organize its orderly wind up.

\section{Legal and judicial reform}

- Accord high priority to achieving a compromise on the land act issues relating to granting of credit.

- Institute reforms in the Companies Law to strengthen the protection of minority shareholders.

- Provide additional resources to the commercial court for rapid settlement of cases.

- Undertake a broader strengthening of the judicial system, as well as the modernization of the company and land registries.

\section{Long-term investment}

- Liberalize investment requirements for insurance companies.

- Facilitate the emergence of securitized loans or guaranteed bonds by pension funds in preference to non-transparent lending to government-sponsored entities.

Managing systemic liquidity, market intervention, and infrastructure

- Develop a sterilization plan to respond to the evolving liquidity situation and inflows.

- Undertake analytical work on money demand.

- Reduce the frequency of money and foreign exchange market interventions; facilitate the development of interbank money and foreign exchange markets.

- Revisit strategy for primary market issuance, consider a more gradual approach to lengthening the yield curve.

- Increase transparency of monetary policy and debt market operations.

- Address weaknesses of payment and securities settlement systems relating to finality and settlement risk.

Bank regulation and supervision

- Immediate review and relaxation of unduly constraining regulations (collateral requirement for large loans; aggregate large loan limits; fixed asset ceiling for banks), and tighten some loopholes (exposure to individual offshore banks).

- Move toward a risk-based supervision system and continue strengthening capacity and techniques for on-site and offsite supervision.

Crisis preparedness

- Develop a financial system crisis prevention and management plan; strengthen the financial safety net through clarifying BOT's LOLR role, and ensure that the role of the Deposit Insurance Fund (DIF) is confined to that of a pay box.

1/ The recommendations in each area are listed in an approximate order of priority.

2/ A detailed matrix of recommendations and specific required actions was left with the authorities as a first step in the development of a comprehensive plan of further reforms, capacity building and related technical assistance. 


\section{OVERVIEW Of THE FINANClal System}

\section{A. Institutions}

10. The Tanzanian financial system is diverse, but concentrated in commercial banking and very small in relation to the economy. It comprises 21 banks, which can be subdivided into three main categories: large domestic banks, subsidiaries of major international banks, and small, mostly domestic, banks; non-bank financial institutions (9), ${ }^{1}$ pension funds ( 2 that invest in financial assets), insurance companies (14), exchange bureaus (63), savings and credit cooperatives SACCOs (about 650 functioning), several hundred other micro-finance institutions (MFIs), and a stock exchange (Table 1).

11. Banks account for about 80 percent of the financial system's assets, ${ }^{2}$ and by far the largest number of customers (depositors). However, bank deposits total only about 14 percent of GDP, and bank credit to the private sector at about 6 percent of GDP is among the lowest in Sub-Saharan Africa. Foreign participation in the banking sector is sizeable and growing. Foreign equity participation accounts for about two-thirds of banking system capitalization, and 57 percent of total banking assets are in banks with majority foreign bank ownership. Approximately 13 percent of banking system capital and 19 percent of banking assets remains state owned.

12. Concentration in the banking system is rather low. Calculations using the Herfindahl index suggest that concentration in lending is broadly equivalent to a system with nine banks of equal size (eight in deposits). Furthermore, the system has been open to entry and as such appears quite contestable. Although the different groups of banks do concentrate in different submarkets there is sufficient overlap in service provision to prevent the market from being segmented. The average loan to deposit ratio is low at only 34 percent. The three large domestic banks which between them have 54 percent of total deposits, reflecting their wide branch network, account for only 24 percent of loans, while the international banks lend a somewhat higher percentage of their deposits ( 60 percent) and account for 57 percent of total private sector credit. The loan to deposit ratio varies widely among the small banks, but on average small banks lend over 40 percent of deposits.

\section{There has been a steady growth in the share of foreign currency denominated} deposits, which now account for 35 percent of the total. The growth has been due in part

\footnotetext{
${ }^{1}$ These are in essence banks with a limited license prohibiting the issue of checking accounts, but enjoying a lower capital adequacy requirements and no minimum reserve requirements. Total assets of the nonbank financial institutions are equivalent to only 6 percent of commercial bank assets.

${ }^{2}$ The three large domestic banks (National Bank of Commerce (NBC), National Microfinance Bank (NMB), and Cooperative and Rural Development Bank (CRDB)) account for 49 percent of the system's assets; the four subsidiaries of major international banks (Citibank, Standard Chartered, Stanbic, and Barclays) account for a further 41 percent; and 14 small banks account for the remainder. NMB is the only large bank in state ownership.
} 
to a repatriation of dollar funds held offshore by Tanzanian nationals - apparently due to the opportunity to keep dollar deposits legally in Tanzania and an expanded offer of deposit services by international banks - though more recently the depreciation of the shilling and low shilling interest rates may also have contributed. Almost all of these dollar deposits are with foreign-owned banks which place them in the international money markets.

14. The spread between bank lending and deposit rates has declined recently, but remains high. Weighted average lending rates (for domestic currency lending) were 14-15 percent in early-2003, while deposits paid are approximately 3 percent, implying a hefty spread of $11-12$ percent. $^{3} \mathrm{~A}$ large part of the spread can be explained by high risk premium charged by the banks for credit risk, weak market infrastructure, and difficulties in enforcement of creditor rights. Rates charged for micro loans are even higher, ranging between 20 and 48 percent flat rate (corresponding to a much higher true interest rate).

Table 1. Tanzania: Financial System Structure, 1998-2002

\begin{tabular}{|c|c|c|c|c|c|c|c|c|c|c|c|c|}
\hline & \multicolumn{2}{|c|}{$\begin{array}{c}\text { Dec. } 1998 \\
\text { Assets }\end{array}$} & \multicolumn{2}{|c|}{$\begin{array}{c}\text { Dec. } 1999 \\
\text { Assets }\end{array}$} & \multicolumn{2}{|c|}{$\begin{array}{c}\text { Dec. } 2000 \\
\text { Assets }\end{array}$} & \multicolumn{2}{|c|}{$\begin{array}{c}\text { Dec. } 2001 \\
\text { Assets }\end{array}$} & \multicolumn{2}{|c|}{$\begin{array}{c}\text { Dec. } 2002 \\
\text { Assets } \\
\end{array}$} & \multicolumn{2}{|c|}{ Dec. 2002} \\
\hline & $\begin{array}{l}\text { T Sh } \\
\text { (bn) }\end{array}$ & $\%$ & $\begin{array}{l}\text { T Sh } \\
\text { (bn) }\end{array}$ & $\%$ & $\begin{array}{l}\text { T Sh } \\
\text { (bn) }\end{array}$ & $\%$ & $\begin{array}{l}\text { T Sh } \\
\text { (bn) }\end{array}$ & $\%$ & $\begin{array}{l}\text { T Sh } \\
\text { (bn) }\end{array}$ & $\%$ & Number & $\begin{array}{c}\% \\
\text { GDP }\end{array}$ \\
\hline \multicolumn{13}{|l|}{ Depository institutions } \\
\hline Commercial banks-total & 1,379 & 78 & 1,339 & 75 & 1,484 & 75 & 1,655 & 75 & 2,126 & 78 & 21 & 23 \\
\hline Large domestic banks l/ & 994 & 56 & 936 & 53 & 833 & 42 & 825 & 38 & 1,033 & 38 & 3 & $1 \mathrm{I}$ \\
\hline Major international banks $2 /$ & 315 & 18 & 403 & 23 & 534 & 27 & 692 & 31 & 876 & 32 & 4 & 10 \\
\hline Other banks & 70 & 4 & 97 & 5 & 117 & 6 & 138 & 6 & 217 & 8 & 14 & 2 \\
\hline SACCOs & $\ldots$ & $\ldots$ & 14 & 1 & 14 & 1 & 15 & 1 & & $\ldots$ & $\ldots$ & ... \\
\hline Other non-bank financial institutions & 103 & 6 & 103 & 6 & 119 & 6 & 121 & 6 & 134 & 5 & 9 & l \\
\hline \multicolumn{13}{|l|}{ Non-depository intermediaries } \\
\hline Insurance companies & 85 & 5 & 90 & 5 & 91 & 5 & 100 & 5 & 98 & 4 & 14 & $\mathrm{l}$ \\
\hline Life and Retirement & 30 & & 21 & & 20 & & 22 & & 21 & & 4 & \\
\hline Nonlife & 54 & & 69 & & 71 & & 78 & & 77 & & 10 & I \\
\hline Pension funds & 195 & 11 & 231 & 13 & 262 & 13 & 309 & 14 & 368 & 13 & 3 & 4 \\
\hline PPF & 72 & & 83 & & 92 & & 107 & & 127 & & 1 & 1 \\
\hline NSSF & 123 & & 148 & & 170 & & 202 & & 241 & & 1 & 3 \\
\hline GEPF & 2 & & 0 & & 2 & & 3 & & $\ldots$ & & 1 & ... \\
\hline Total financial system assets $3 /$ & 1,761 & & 1,776 & & 1,970 & & 2,200 & & 2,726 & & & 30 \\
\hline
\end{tabular}

Sources: Bank of Tanzania and staff calculations.

I/NBC, NMB, and CRDB.

2/ Citibank, Standard Chartered, Stanbic, and Barclays.

$3 /$ Sixty threc exchange bureaus and several securities firns excluded due to unavailability of data. Estimates suggest they are rather smail.

15. The use of formal banking services remains limited (Box 2). According to the 2000-01 Household Budget Survey (HBS), in only 6.4 percent (or about 450,000) of all households was there a member with a saving or current account-down from 18 percent a decade earlier-and the corresponding figure was only 3.8 percent in rural areas. This decline reflects in part recent restructuring of the banking system when a number of bank branches were closed. Outside of the provincial capitals, the main banking presence is that of the NMB and the agency relationship which the Tanzania Postal Bank (TPB) has with about 120 branches of the post office system.

\footnotetext{
${ }^{3}$ The lending rates and the spread declined from about 20 percent and 16 percent, respectively, in early-2001 to the current levels in early-2002 and stayed generally flat since.
} 


\section{Box 2. Access Survey Results 1/}

Households and enterprises make extensive use of informal mechanisms to hold savings, obtain credit and perform money transfers, even in areas relatively well served by formal financial institutions, such as Dar es Salaam, Arusha, Mbeya, and Kilimanjaro. The findings suggest that an unmet demand exists for formal services, as long as formal financial institutions can offer products that emulate informal services, i.e., satisfy a revealed demand, while being superior to informal products in at least one feature, for instance, improved safety in the case of savings.

Savings practices. A vast majority of households hold savings in some form. Awareness of and use of bank deposit services appears to be much higher than that observed in countries of comparable or even higher GDP per capita. This finding is associated with the extensive networks of both TPB and NMB, and to a lesser extent of Cooperative and Rural Development Bank (CRDB).

Informal, physical forms of savings (quasi-liquid assets) such as livestock and inventories dominate the asset portfolios of households and of small enterprises, aside from intermediate inputs held for use in production. Financial forms of informal savings, such as keeping cash at home and participating in rotating savings and credit associations (upatus) are also reported. Although cultural factors certainly determine some observed practices, such as holding livestock as main form of savings among the Maasai, in most cases a suitable deposit instrument could conceivably substitute for physical assets exposed to loss, theft, and depreciation.

Focus-group participants pointed to deficiencies in bank deposit services, such as negative real returns and poor service, for instance, lack of assistance to fill in forms, as deterrents to hold accounts with banks. Some "forced savings" mechanisms, such as paying installments to a dealer toward the purchase of a consumer curable and taking delivery only when it is fully paid, could easily be replaced with a deposit instrument that better protects the interest of the buyer. Developing new instruments and improving services, however, may only occur when financial intermediaries look to substantially increase deposit collection, a move that seems unlikely in the current generalized overly liquid situation of most banks.

Access to credit. The recent proliferation of microfinance programs and the practice of microfinance by established banks, such as $\mathrm{CRDB}$, Akiba and more recently $\mathrm{NMB}$, appears to have improved access to formal credit relative to the dismal incidence of formal credit documented both in the 1997 survey and the 2000-01 Household Budget Survey (about one percent of households with bank loans). Botrowing from microfinance nongovernmental organizations (NGOs) such as PRDE (in urban areas) and from SACCOs and the Savings and Credit Associations (SACAs), both urban and rural, was reported as relatively easier compared to banks, as those entities do not require collateral and/or they have location advantages over banks, or come to the client, as is the case of NGO loan officers.

Access to credit, however, remains limited and discouraged by conditions perceived as complex (bureaucracy, lack of transparency in procedures) or impossible to meet (collateral requirements). Moreover, complaints of corruption especially in government-sponsored credit programs were voiced in several instances.

The introduction of group-guarantee lending methods has clearly made a difference for micro and small entrepreneurs to access credit. The rigidities associated with this mechanism, such as a pre-established progression in loan amounts, and the ineligibility of start-up enterprises, are cited as negative feazures.

Money transfers. Money transfers in the study areas are carried out primarily through the Tanzania Postal Bank (TPB), either via telegraphic money orders or via Western Union services, and commercial banks services (NBC, NMB, CRDB), for which transfers represent an important source of fee income. Among informal mechanisms, a popular means of transferring money is to use physical transfer of cash by traders or relatives. In addition, a bus company with a fairly extensive service network provides organized arrangements for physical transfers of money, at a cost that ranges between 3.5 percent and 8 percent of the amount transferred (or higher for very small amounts). The amount transferred is guaranteed by the bus company. Its services were praised for their reliability and simplicity.

1/ A field study conducted as part of the FSAP work, based on focus groups of households and micro/small enterprises in both urban and rural areas, provided qualitative insights into the availability, costs and requirements of a range of financial services. The study, conducted in six regions, built upon a large scale sample survey carried out in 1997, and helped confirm and update the latter's main findings and implications. The regions included in the focus-group study were Arusha, Dar es Salaam, Kilimanjaro and Mbeya, all considered relatively well served by formal financial institutions, plus Kigoma and Mtwara, selected as poorly served areas. 
16. About 250 Savings and Credit Cooperatives (SACCOs) are in urban areas,
based on a common place of employment and with a total membership in 2001 of $\mathbf{5 0 , 0 0 0}$. The remaining 400 rural SACCOs, mostly community-based, have a total membership of over 83,000 , but are much smaller in scale with an average loan book of about T Sh 3 million per society. The total value of the 30,000 or so loans in both kinds of SACCO came to less than T Sh 7 billion in 2001. Of the other MFIs, the donor-sponsored non-governmental organizations (NGOs) are the largest and may have as many as 100,000 borrowers, with total loans outstanding of more than T Sh 10 billion. The NGOs are not strictly speaking deposit takers, though their approach in Tanzania as elsewhere typically involves an element of forced savings.

17. The symptoms of structural weakness in Tanzania's financial system need to be viewed in the context of the weak financial infrastructure (Box 3 ). These include the environment for contract enforcement, and the efficiency of the legal, judicial, and information framework. Comparative figures as assessed in recent international surveys, suggests that problems such as delays and elaborate procedures for contract enforcement are by no means unique to Tanzania (Table 2). Respondents to another published survey concerning access to credit reveal interesting contrasts between Tanzania and other countries in the perceived obstacles to accessing funds: Tanzanian respondents were less likely to see corruption of bank officials or a lack of funds in the banks as the source of problems, but more likely to complain about collateral requirements, the lack of leasing, equity and export finance, and well as the absence of credit information.

\section{Box 3. Functional Effectiveness of the Financial System}

Concerning the effectiveness of the Tanzanian financial system in performing the main functious of finance, most of these hinge largely on the banking sector and, for poor households, the microfinance sector. This is most evident in payments and the mobilization of funds, but also applies to the other key functions, such as provision of liquidity and term transformation; risk management and transfer; allocation of investable resources; and monitoring and control of corporations. In turn, the modest scale of the banking system in the economy, and the simple, heavily collateralized lending and short-term instruments which it mainly uses, indicates the limited effectiveness with which these functions are being performed.

Liquidity provided by the financial system is mainly in the form of cash, current accounts and time deposits, each accounting for about 6-7 percent of GDP at end-2002. Not only are these figures small, but the coverage of the population is equally small (6 percent of households). The equity free-float is about 1 percent of GDP, and, this can be considered liquid even though the secondary market is shallow and inactive, since any seller will easily find a willing buyer near current prices. The same is true of bonds, but almost all of these are held by banks, pensions funds and insurance companies rather than by nonfinancial entities. But, instead of this bank liquidity being the result of intermediation of longer-term and illiquid obligations of the private sector, about two-thirds is backed by the banking system's large holdings of foreign liquid assets, and the remainder is almost all of less than one year's maturity. Part of this preference for foreign holdings surely comes from the private sector's preference for dollar deposits. As in most countries, a large fraction of those funds mobilized in dollar-denominated form cannot prudently be placed at home in view of exchange risk.

Maturity transformation for the private sector is also negative overall. The loan to deposit ratio extremely low, and much of the long-term liabilities of the pension funds are invested in bank deposits, treasury bills or short-term bonds. As such one important natural supply of long-term funds to finance private sector development fails to be passed through. Liquidity aside, other forms of risk reduction are romally provided in the financial sector by insurance and by the risk-pooling entailed in stock market portfolios. Here again the very small size of these sectors in Tanzania limits their role. Furthermore, the stock market is not at all well-diversified. There is essentially no risk-reduction in the form of derivatives. As there is no natural counterpart to risk reducing deals, there is eventually no market for derivatives. The modest investment by institutional investors such as investment and pension funds in equities (less than 3 percent of the market) limits their role in exercising corporate governance, which again devolves to the banks through their exercise of credit allocation decisions. That in turn is limited by the fact that the bulk of these loans are short term. Banks refy heavily on collateral and guarantees for their security. 
18. The nonbank component of Tanzania's financial system is limited in terms of volume of activity, range and quality of its products and services, and degree of market penetration. Total insurance premia come to little over half a percent of GDP. New entrants since 1998 have strongly eroded the former monopoly of the National Insurance Corporation (NIC) in general (non-life) insurance, though the latter retained a 22 percent market share in 2002 and still has almost all of the nascent life assurance business. Total assets of the insurance industry at end-2001 were T Sh 116 billion or a little over 1 percent of GDP. The two major second-tier pension funds covering private sector and parastatal employees, National Social Security Fund (NSSF) and Parastatal Pension Fund (PPF), have between them accumulated assets of T Sh 368 million, or almost 4 percent of GDP and they continue to accumulate cash surpluses which are invested in a range of domestic assets.

19. The stock exchange will list its sixth equity share in June 2003. Equity market capitalization at end-2002 was T Sh 690 billion or 7 percent of GDP, of which some 86 percent are held by foreign parents, other controlling shareholder blocks, or government agencies (not including the pension funds) leaving the free float of shares at just 1 percent of GDP. Equity trading is very light, amounting to an annual turnover ratio of under 3 percent. Very recently the stock exchange has been opened (with some important restrictions) to foreign portfolio investment and to cross-listings.

Table 2. Tanzania: International Comparison of Selected Development Indicators

\begin{tabular}{|c|c|c|c|c|c|c|c|c|c|}
\hline & Tanzania & Kenya & Zambia & Mozambique & Zimbabwe & Nigeria & $\begin{array}{l}\text { South } \\
\text { Africa }\end{array}$ & Pakistan & India \\
\hline \multicolumn{10}{|l|}{ Size of financial intermediaries ( $k J s)$} \\
\hline Private credit to GDP $1 /$ & 4.9 & 26.8 & 7.5 & 16.7 & 19.8 & 14.4 & 147.2 & 27.9 & 29.0 \\
\hline $\mathrm{M} 2$ to GDP & 18.3 & 43.8 & 16.9 & 25.1 & 21.9 & 25.8 & 87.2 & 46.5 & 51.9 \\
\hline \multicolumn{10}{|l|}{ Banking inclustry } \\
\hline Number of banks 17 & 29 & 53 & 16 & 10 & $\ldots$ & 51 & 60 & $\ldots$ & 103 \\
\hline Net interest margin & 6.5 & 5.0 & 11.4 & 5.9 & 5.8 & 3.8 & 5.0 & 2.6 & 2.9 \\
\hline Overhead costs & 5.1 & 3.7 & 9.8 & 4.5 & 6.8 & 8.5 & 3.7 & 2.6 & 1.5 \\
\hline Foreign bank share (assets) & $\mathbf{5 8 . 7}$ & 4.8 & 66.6 & 98.0 & 59.0 & 1.0 & 0.6 & 41.7 & 32.9 \\
\hline Bank concentration (3 banks) & 45.8 & 61.6 & 81.9 & 76.6 & 88.3 & 86.5 & 77.0 & 56.0 & 88.1 \\
\hline \multicolumn{10}{|l|}{ Capital and insurance markets } \\
\hline Number of companies listed & 5 & 114 & 15 & $\ldots$ & 73 & 195 & $\ldots$ & 765 & 6959 \\
\hline Stock market capitalization to GDP (\%) & 7.6 & 18.2 & 11.6 & $\cdots$ & 43.9 & 8.2 & 192.2 & 11.7 & 66.3 \\
\hline Stock market value traded to GDP $(\%)$ & 0.2 & 0.6 & 0.2 & $\ldots$ & 8.4 & 0.4 & 34.8 & 34.8 & 105.2 \\
\hline Insurance premium to GDP & 0.6 & 2.7 & $\cdots$ & $\cdots$ & 3.7 & 0.7 & 18.0 & 0.7 & 2.7 \\
\hline \multicolumn{10}{|l|}{ Contract enforcement } \\
\hline $\mathrm{Nr}$, of procedures & 14 & 25 & 16 & 18 & 13 & 25 & 11 & 30 & 22 \\
\hline Duration (days) & 127 & 255 & 188 & 540 & 197 & 241 & 84 & 365 & 106 \\
\hline Formalism index & 3.8 & 3.1 & 2.1 & 4.5 & 3.1 & 3.1 & 1.7 & 3.8 & 3.3 \\
\hline \multicolumn{10}{|l|}{ Credit markets } \\
\hline Existence of credit bureaus & No & No & No & Yes & Yo & Yes & No & Yes & No \\
\hline \multicolumn{10}{|l|}{ Bankruptcy } \\
\hline Time in years & 3 & 4.6 & 3.7 & 3 & 2.3 & 1,6 & 2 & 2.8 & 11.3 \\
\hline Cost, $1+$ best. $j=$ worst & 3 & 4 & 3 & 3 & 3 & 4 & 4 & 2 & 3 \\
\hline Governance index $(0$ to 10$)$ & 4.0 & 3.4 & 3.9 & 4.2 & 2.5 & 2.7 & 5.8 & 3.3 & 4.7 \\
\hline \multicolumn{10}{|l|}{ Entry regulations } \\
\hline Nr. of procedures & 13 & 11 & 6 & 16 & 10 & 9 & 9 & 10 & 10 \\
\hline Duration (days) & 37 & 68 & 40 & 214 & 122 & 50 & 32 & 53 & 88 \\
\hline Cost (\% of GNI per capital) & 229 & 44 & 43 & 74 & 27 & 92 & 7 & 44 & 51 \\
\hline \multicolumn{10}{|l|}{ Development indicators } \\
\hline GNI per capita (US\$) & 263 & 350 & 316 & 220 & 463 & 266 & 3050 & 436 & 450 \\
\hline Agriculture VA to GDP & 45 & 20 & 22 & 24 & 18 & 30 & 3 & 27 & 25 \\
\hline Illiteracy rate, adult & 25 & 18 & 22 & 56 & 11 & 36 & 15 & 57 & 43 \\
\hline Acc. to water ( $\%$ of population) & 68 & 57 & 64 & 57 & 83 & 62 & 86 & 90 & 84 \\
\hline Percent rural population & 68 & 67 & 60 & 68 & 65 & 56 & 43 & $6 \overrightarrow{7}$ & 72 \\
\hline
\end{tabular}

Source: International Financial Statistics, Banscope, World Developnent Indicators, LexMundi, and KKZ Governance.

Data mostly for 2000 and 2001 .

1/ Data for Tanzania include eight deposit-taking non-bank financial institutions. Tanzanian data on private credit and M2 to GDP are fronz 2001 to ensure consistency with other countries, but they differ from the 2002 data reported in the text. 


\section{B. Markets}

20. Tanzanian financial markets are largely underdeveloped. The interbank money market is thin with volume of transactions per month varying between T Sh 97 billion and T Sh 276 billion (or 4.6 percent and 13 percent of broad money) during all of 2002 . The development of the market has been slow largely because of the substantial excess liquidity in the banking sector. The market is segmented between large and small banks, with the large banks unwilling to deal with counterparties that are perceived to be in weak condition. Lending continues to be on an unsecured basis with the bulk of transactions concentrated in the overnight tenor. Intraday variations in interest rates are small (about 25 basis points).

21. The interbank foreign exchange market is also thin. ${ }^{4}$ Although both banks and nonbank financial institutions are allowed to deal in foreign exchange, the major participants are the BOT and about seven major banks, mainly foreign owned. There are also 63 exchange bureaus licensed to buy and sell foreign currency cash, traveler's checks and other foreign currency instruments. The BOT dominates the market and intervenes regularly to meet mismatches in demand and supply arising from the seasonal nature of flows and to smoothen exchange rate movements. There are no forward markets although a few banks have structured some forward transactions for their customers.

22. The primary market for treasury bills is well established, with a full compliment of maturities offered out to one year, but there is practically no secondary market trading. The total stock of outstanding government securities was T Sh 704 billion at endDecember 2002 (8 percent of GDP), including treasury bills for 35-364 days (T Sh 506 billion) and 2-year to 10-year bonds (T Sh 197 billion). Treasury bills are used for both government financing operations and monetary policy purposes, with the only distinction between them being the BOT's internal accounting treatment-interest on financing papers is a charge against the government, while interest on liquidity papers is met by the BOT. Treasury bills are held mostly by banks (74 percent) while bonds are predominantly subscribed to by institutional investors-pension funds and insurance companies together held just over 70 percent while banking institutions held 26 percent. The government bonds, as well as two bonds of the East African Development Bank, are also listed on the stock exchange, but there is practically no secondary market trading in these or in treasury bills. The development of an active secondary market has been inhibited by the recent high level of excess liquidity in the banking sector and by the absence of alternative investment opportunities. Banks and institutional investors tend to buy government securities as their main investment and keep them until maturity.

\footnotetext{
${ }^{4}$ Turnover is showing an upward trend, however. It has gone up from US\$517 million in 2000 to US\$845 million in 2002. In the first four months of 2003 the total turnover was nearly US $\$ 300$ million, with the number of transactions ranging from 6 to 10 per day.
} 


\section{Recent Macroeconomic Developments}

23. Macroeconomic conditions have been favorable for the financial system recently. Since 1996, Tanzania has made major progress in the implementation of structural reforms and macroeconomic stabilization. Fiscal consolidation has been essential for the success in macroeconomic stabilization. The recent strong growth performance mostly stemmed from improvements in total factor productivity, likely reflecting the effect of structural reforms. The strong growth performance has been accompanied by falling inflation rates, down from 30 percent during $1990-95$ to below 5 percent in 2002 (Table 3 ).

24. Monetary developments have been characterized by strong monetary expansion in recent years, as large foreign aid inflows were not fully sterilized and the demand for broad money expanded. Primarily reflecting the lack of suitable lending opportunities due to insufficient absorption capacity of the economy - caused by structural rigidities--the banking system developed an increasingly large liquidity surplus, which triggered an excess demand for treasury bills and, consequently, a decline in interest rates on bills and deposits. The 91-day treasury bill rate has declined gradually from 15.25 percent in December 2000 to 2.5 percent in September 2002 when banks' excess liquidity peaked. However, since December 2002 the rate firmed significantly, reaching 6.25 percent in April 2003. After a substantial real appreciation in the second half of the 1990s, the real effective exchange rate has been depreciating. In 2002, the Tanzanian shilling depreciated against the U.S. dollar by 7 percent in nominal terms and lost another 5 percent in the first five months of 2003.

25. Despite these recent positive developments, the Tanzanian economy remains small and relatively undiversified, heavily dependent on agriculture. Although per capita income has increased in recent years, Tanzania's GDP per capita at about US\$300 in 2001 (about US\$550 in purchasing power parity) is among the lowest in the world. The recent HBS revealed that some 36 percent of Tanzanians fell below the basic needs poverty line, and 19 percent below the food poverty line. Poverty remains disproportionately rural. Tanzania must therefore continue to pursue economic reforms in order to foster stronger growth.

\section{Vulnerabmities and SOUNDNEsS of the Financial System}

\section{A. Macroeconomic Sources of Risks to Financial Stability}

26. Although the macroeconomic environment has been stable recently, the Tanzanian economy faces several risks. These mainly arise from the structure of the real economy and dependence on large amounts of external donor aid flows. The economy's dependence on agriculture leaves Tanzania highly vulnerable to external shocks-drought and falling world commodity prices. Due to limited processing capacity for agricultural products, there is little room to counter the fluctuations of prices of raw agricultural exports. 
A decrease of earning capacity of the agricultural sector would pose significant risks to macroeconomic stability and the financial system. The economy is also vulnerable to a drop in tourism revenues, which is not unlikely given the current international security concerns. ${ }^{5}$

Table 3. Tanzania: Selected Economic and Financial Indicators, 1998-2002

\begin{tabular}{|c|c|c|c|c|c|}
\hline & 1998 & 1999 & 2000 & 2001 & 2002 prel. \\
\hline & \multicolumn{5}{|c|}{ (Annual percentage change, unless otherwise specified) } \\
\hline \multicolumn{6}{|l|}{ National income and prices } \\
\hline Real GDP growth & 4.0 & 4.7 & 4.9 & 5.6 & 6.2 \\
\hline Real GDP per capita & 0.9 & 2.6 & 1.7 & 2.9 & 4.0 \\
\hline Consumer prices (period average) & 12.8 & 7.9 & 5.9 & 5.2 & 4.6 \\
\hline \multicolumn{6}{|l|}{ External sector } \\
\hline Export volume & -14.5 & -17.6 & 25.8 & 25.9 & 7.0 \\
\hline Import volume & 30.2 & 11.0 & -1.7 & 12.7 & -6.1 \\
\hline Terms of trade (deterioration -) & -2.5 & 24.1 & -2.2 & -6.0 & 5.2 \\
\hline Real effective exchange rate (depreciation -) & -0.7 & -4.6 & 12.2 & -6.8 & -11.6 \\
\hline \multicolumn{6}{|l|}{ Public finance $1 /$} \\
\hline Revenue (excluding grants) & 11.4 & 12.0 & 20.3 & 12.2 & 13.5 \\
\hline Total expenditure & 26.3 & 26.5 & 3.5 & 16.3 & 25.2 \\
\hline Current expenditure & 15.8 & 22.9 & 22.2 & 18.7 & 21.8 \\
\hline Development expenditure and net lending & 25.6 & 45.2 & -20.5 & 1.8 & 52,0 \\
\hline \multicolumn{6}{|l|}{ Money and credit } \\
\hline Broad moncy & 10.8 & 18.6 & 14.8 & 17.1 & 25.1 \\
\hline Net foreign assets & 19.2 & 35.6 & 49.6 & 36.7 & 30.2 \\
\hline Net domestic assets & 5.6 & 6.6 & -16.2 & -14.1 & 12.3 \\
\hline \multirow[t]{2}{*}{ Velocity of money (M3; average) } & 5.7 & 5.7 & 5.6 & 5.4 & 4.9 \\
\hline & \multicolumn{5}{|c|}{ (In percent of GDP, unless otherwise indicated) } \\
\hline \multicolumn{6}{|l|}{ Savings and investment } \\
\hline Resource gap & -14.7 & -12.2 & -8.4 & -9.5 & -7.2 \\
\hline Investment & 16.2 & 15.5 & 17.6 & 17.0 & 17.4 \\
\hline Government & 4.0 & 4.7 & 4.4 & 3.5 & 4.0 \\
\hline Nongoverument & 12.2 & 10.8 & 13.2 & 13.5 & 13.4 \\
\hline \multirow[t]{2}{*}{ Gross domestic savings } & 1.5 & 3.4 & 9.2 & 7.5 & 10.3 \\
\hline & \multicolumn{5}{|c|}{ (In millions of U.S. dollars, unless otherwise specified) } \\
\hline Current account balance (excluding grants; deficit -) & $-1,336$ & $-1,134$ & -856 & -892 & -764 \\
\hline Overall balance of payments (deficit -) & -205 & -68 & 90 & -36 & 285 \\
\hline Gross official reserves & 599 & 776 & 974 & 1,157 & 1,530 \\
\hline In months of imports of goods and nonfactor services & 3.2 & 4.4 & 5.0 & 6.1 & 6.3 \\
\hline
\end{tabular}

Sources: Tanzanian authorities; and Fund staff estimates and projections.

$1 /$ Fiscal years (July-June), beginning in the year indicated in the column header.

\footnotetext{
${ }^{5}$ The global economic slowdown and the security concerns pose near-term macroeconomic challenges, especially to the Zanzibar's tourism industry.
} 
27. While a steady inflow of donor support is critical for the implementation of the poverty reduction program, major delays in aid disbursements and a sudden and sharp drop in aid inflows could expose the country to substantial internal and external imbalances—with consequences for macroeconomic stability and the financial system. Progress in revenue mobilization and reduction in dependency on foreign aid has been slow. External budgetary support is expected to reach about US $\$ 1$ billion (over 10 percent of GDP) in fiscal year $2003-04 .^{6}$ Domestic revenue, at 12 percent of GDP, is low even to cover wages and other charges required for day-to-day government operations and to maintain basic public operations. In case of sudden drop in aid flows, the government would have to resort to BOT financing, reversing the fiscal consolidation achieved so far.

28. On the other hand, large external donor aid inflows themselves, which are often lumpy, are a source of risk to the conduct of monetary policy and, consequently, to the banking system. Monetary mismanagement of large donor inflows may lead to excessive nominal appreciation of the exchange rate or sharp increase of inflation and interest rates, which would harm the competitiveness of the Tanzanian economy and worsen the credit quality of bank loan portfolios.

29. In the longer term, it will be important to properly phase in the planned continuation of capital account liberalization and efforts toward regional integration. These can become sources of vulnerabilities for the financial system unless it is prepared to cope with the new pressures and unless proper safeguards are in place. Also, Tanzania's overlapping membership in several regional groupings results in a duplication of effort and, occasionally, divergent aims in regional integration initiatives. At the same time, there is an inconsistent level of commitment among member states of various initiatives.

\section{B. Macroprudential Analysis}

30. The banking system is generally well capitalized and profitable (Table 4). The banking system's capital adequacy has recovered to over 23 percent of capital to riskweighted assets at the end of 2002 after it had decreased sharply to 13 percent in 1999 , as a result of the restructuring of the country's largest bank, the NBC. The aggregate capital adequacy includes two insolvent banks (the People's Bank of Zanzibar and Delphis Bank), both of which are small and have had problems for some time. ${ }^{7}$ The former is at the start of another restructuring and recapitalization attempt, while the latter was placed under administration by the BOT in March 2003. The three large domestic banks have regulatory risk-weighted CAR between 14 and 30 percent, while it has varied between 12 and 20 percent for the four international banks.

${ }^{6}$ Budgetary support includes both program and project aid.

${ }^{7}$ People's Bank of Zanzibar and Delphis Bank account for 1.5 percent and 0.2 percent of the banking system's assets, respectively. 
Table 4. Tanzania: Financial Soundness Indicators for the Banking Sector, 1998-2002 (In percent, unless otherwise indicated)

\begin{tabular}{|c|c|c|c|c|c|}
\hline & $\begin{array}{l}\text { Dec. } \\
1998\end{array}$ & $\begin{array}{l}\text { Dec. } \\
1999 \\
\end{array}$ & $\begin{array}{l}\text { Dec. } \\
2000 \\
\end{array}$ & $\begin{array}{l}\text { Dec. } \\
2001\end{array}$ & $\begin{array}{l}\text { Dec. } \\
2002 \\
\end{array}$ \\
\hline \multicolumn{6}{|l|}{ Capital adequacy } \\
\hline Capital to risk-weighted assets* $1 /$ & 19.2 & 12.9 & 21.8 & 24.1 & 23.1 \\
\hline Capital to assets & 6.5 & 3.8 & 9.6 & 9.6 & 8.6 \\
\hline \multicolumn{6}{|l|}{ Asset composition and quality } \\
\hline \multicolumn{5}{|l|}{ Sectoral distribution of loans to total loans* } & 25.4 \\
\hline Trade & 26.0 & 25.2 & 26.4 & 33.1 & 21.2 \\
\hline Manufacturing and mining & 23.1 & 29.3 & 31.4 & 33.6 & 16.1 \\
\hline Agricultural production & 7.5 & 5.7 & 6.3 & 9.6 & 11.2 \\
\hline Building and construction & 2.3 & 2.1 & 3.4 & 3.4 & 9.8 \\
\hline Transport & 9.1 & 11.0 & 13.5 & 10.1 & 9.2 \\
\hline FX loans to total loans & 22.8 & 32.7 & 32.2 & 32.3 & 28.1 \\
\hline Gross NPLs to gross loans* & 22.9 & 25.2 & 17.3 & 12.0 & 9.2 \\
\hline NPLs net of provisions to capital* & 97.4 & 191.7 & 51.5 & 36.0 & 2.9 \\
\hline Large exposures to capital* 3 / & $\ldots$ & $\cdots$ & $\cdots$ & 44.7 & 58.2 \\
\hline \multicolumn{6}{|l|}{ Earnings and profitability } \\
\hline $\mathrm{ROA}^{*}$ & 1.9 & 0.1 & 1.3 & 1.2 & 1.3 \\
\hline $\mathrm{ROE}^{*}$ & 45.6 & 2.1 & 20.5 & 21.4 & 17.6 \\
\hline Interest margin to gross income* & 37.6 & 42.1 & 41.9 & 42.5 & 41.6 \\
\hline Noninterest expenses to gross income* & 46.7 & 46.7 & 49.1 & 58.8 & 60.8 \\
\hline Personnel expenses to noninterest expenses & 44.7 & 38.5 & 40.6 & 37.6 & 41.3 \\
\hline Trading and fee income to total income & 37.5 & 32.8 & 24.8 & 40.1 & 45.3 \\
\hline Interest rate earned on loans and advances & $\ldots$ & 18.4 & 17.8 & 15.3 & 13.3 \\
\hline Interest rate paid on non-bank deposits & $\ldots$ & 3.9 & 3.3 & 2.3 & 1.4 \\
\hline Spread (lending and deposit dates) & $\ldots$ & 14.5 & 14.5 & 13.1 & 11.9 \\
\hline \multicolumn{6}{|l|}{ Liquiality } \\
\hline Liquid assets to total assets* & 32.9 & 31.2 & 50.9 & 56.5 & 58.0 \\
\hline Liquid assets to total short-term liabilities* & 37.1 & 33.8 & 65.5 & 67.0 & 68.9 \\
\hline Total loans to customer deposits & 32.9 & 33.0 & 31.1 & 29.8 & 34.1 \\
\hline FX liabilities to total liabilities & 17.3 & 18.0 & 28.3 & 33.3 & 34.1 \\
\hline \multicolumn{6}{|l|}{ Sensitivity to market risk } \\
\hline Net open positions in FX to capital ${ }^{*}$ 4/ & 110.6 & 148.2 & 68.6 & 52.0 & 23.0 \\
\hline \multicolumn{6}{|c|}{$\begin{array}{l}\text { Source: Bank of Tanzania and staff calculations. Note: Profitability and capitalization were affected by a restructuring } \\
\text { of the country's largest bank in } 1999 . \text { Also, new reporting regulations were introduced in } 2000 . \\
\text { *Included in the "core set" of FSIs. } \\
1 \text { Virtually all capital in the banking system is Tier } 1 \text { capital. }\end{array}$} \\
\hline
\end{tabular}

\section{The institutional environment, including market and legal infrastructure and} credit culture, is underdeveloped, but the banking regulatory and supervisory framework appears to reflect this sufficiently. Loan classification regulations are appropriate and provisioning rules are conservative, with collateral assumed to have zero value when making provisions. Connected lending is not a large problem according to reported data. Asset valuation also appears to be broadly appropriate. 


\section{Banking system profitability has recovered after the $\mathrm{NBC}$ restructuring} depressed profits substantially in 1999. Between 2000 and 2002, return on equity has been in the proximity of 20 percent. International banks have the highest rate of operating profit, followed by large domestic banks. Large domestic banks pay the lowest interest on deposits, but their large branch network increases their non-interest costs to 63 percent of total gross income in 2002. International banks paid over 3 percent of total revenues to other banks on interbank borrowings, but were able to keep non-interest expenses below 50 percent of total gross income.

33. Some small banks appear to be struggling. They have been paying higher interest rates on deposits, and also have high non-interest expenses. This makes their profitability performance rather unimpressive, and requires close supervisory watch. There exists, however, large differentiation among small banks, with some banks posting healthy profits while others operate deep in red figures. Besides the already insolvent Delphis Bank, three small banks and one financial institution (quasi-bank) recorded losses in 2002. Two of them appear well capitalized, but the other two are a reason for concern, particularly as one of them emerged as rather weak in the stress testing exercise.

\section{Asset quality as measured by loan-loss provisioning, appears to be satisfactory.} The ratio of nonperforming loans to total gross loans was 9 percent at the end of 2002, lower than in earlier years. Financial restructuring of formerly state-owned banks is one of the key reasons for the decline. ${ }^{8}$ Strict provisioning requirements, which disallow the value of collateral, significantly decrease the balance sheet value of non-performing loans. At the end of 2002, the ratio of net nonperforming loans to capital was only 3 percent as most nonperforming loans fell to the loss category and were fully provisioned for. As for sectoral lending exposures, trade remains the most important sector, with mining and manufacturing, agriculture, and building and construction, being other key sectors. Lending to agriculture and building and construction has grown dramatically since early-2001.

\section{Bank balance sheets appear highly liquid, with large holdings of government} securities and offshore deposits. This should, however, be viewed with caution because of the shallowness of the secondary market for government bonds and the fact that both the interbank money market (where treasury bills could be used as collateral) and the foreign exchange market are very thin and dependent on BOT liquidity support. Liquidity in foreign currency is ample, since offshore foreign exchange placements cover 77 percent of customer deposits in foreign exchange. At the end of 2002,24 percent of total assets were placed in banks abroad.

\footnotetext{
${ }^{8}$ The loan portfolios of the three banking institutions that are still owned by the government are small and appear either healthy (NMB and TIB) or well provisioned (TPB).
} 
36. A major state-owned insurer is insolvent and pension funds are probably underfunded, but neither is currently relevant from the systemic point of view. The former monopoly, NIC, is insolvent, has a staggering number of unsettled claims, poor service record, and high operating costs. Pension funds have currently positive cash flow, but no reliable actuarial estimates of their future liabilities exist and their defined benefit schemes appear likely underfunded. Operating costs of pension funds are very high.

\section{Risks and Vulnerabilities}

37. The sensitivity of the Tanzanian financial system to credit risk, interest rate risk, exchange rate risk, and the risk of a change in interest spreads, was assessed through stress tests on individual banking institutions. Stress test results suggest that the Tanzanian financial system is generally resilient to shocks (Table 5). The only major risk area identified by the stress tests is interest rate risk. Although the vast majority of lending is short term, two large banks have significant holdings of government bonds which expose them to considerable interest rate risk as the liability side of their balance sheet would reprice very quickly in case of a significant increase of interest rates.

38. Overall, the exposure to credit risk is limited since loans and overdrafts account for only one quarter of banking assets. Even with a very large credit shock, making 50 percent of all loans nonperforming, 80 percent of the banking system (as measured by assets) would still be left with positive capital. However, as banks undertake new and expanded lending activities, credit risk factors could grow. Supervisory attention must therefore remain focused in this area.

39. Although the concentration of sectoral exposures is not very large, concentration of credit to individual borrowers is a source of concern. Aggregate exposure to individual borrowers is rather large as a failure of the five largest borrowers would wipe out almost 60 percent of the total banking system capital. These borrowers, however, operate in different sectors, which considerably lowers the probability of such an event. This issue, however, warrants careful monitoring. Placement of large dollar deposits in offshore banks is another potential source of concentrated credit risk. The existing lax regulations in this area (which allow as much as 60 percent of total placements in one A-rated bank, or as much as 20 percent in an unrated bank) would not be sufficient to guard against this in view of the very high ratio of foreign placements to capital. In aggregate, 20 percent of balances in banks abroad equals almost 50 percent of capital; for individual banks as much as 130 percent of capital. 
Table 5. Tanzania: Summary of Stress Test Results 1/

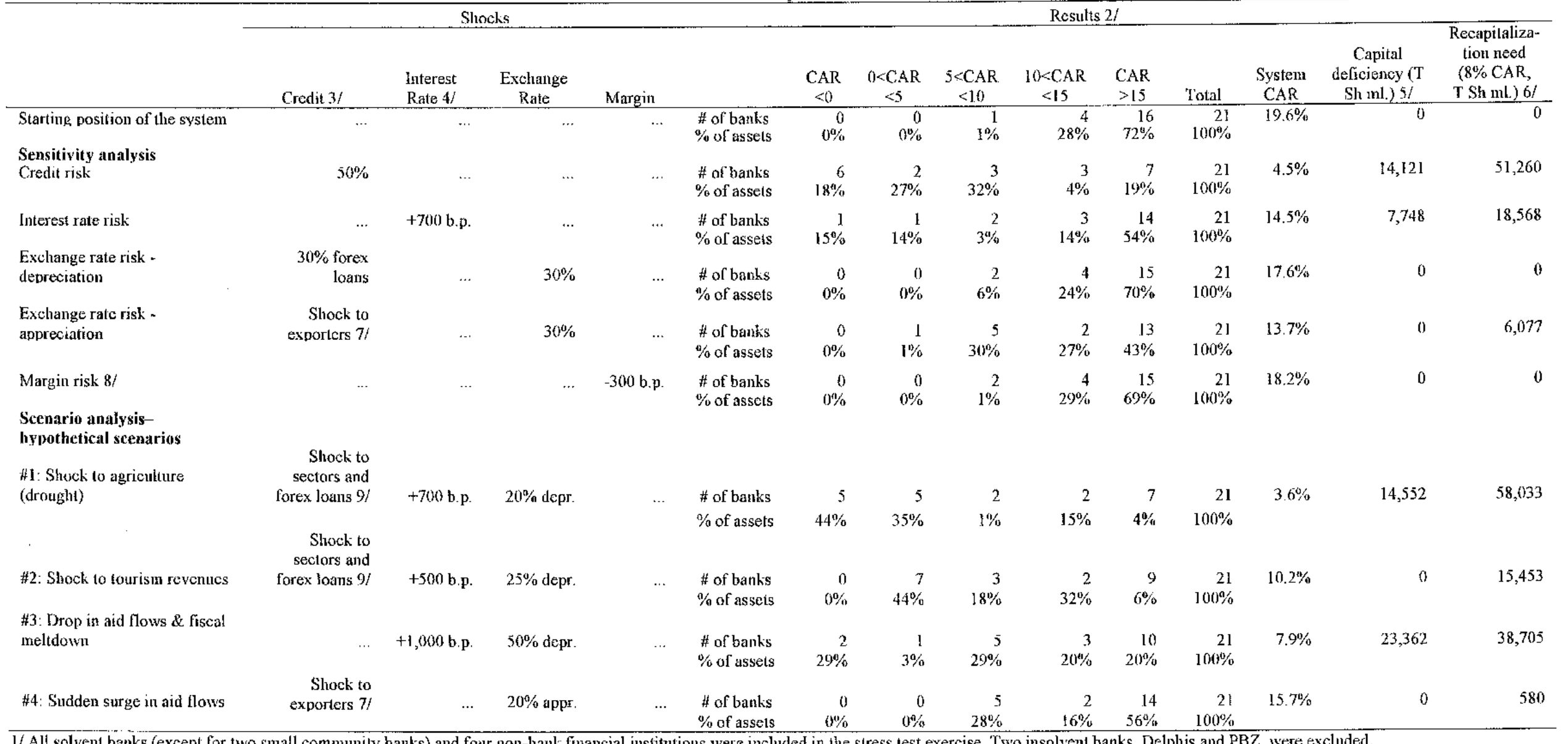

1/ All solvent banks (except for two small community banks) and four non-bank financial institutions were included in the stress test exercise. Two insolvent banks, Delphis and PBZ, were excluded.

2/ CAR stands for capilal adequacy ratio.

3/ Percentage of oustanding loans becoming nonperforming, with even distribulion from substandard to loss. Provisioning with zcro valuc collaterat assumption

"Forex loans" means an analogous shock to loans dcnominated in forcign exchange.

4/ Impact over a one-year period of a parallct shift of the yield curve. Interest rates on interest bearing assets and interest paying liabilities change by the same amount; b.p. stands for basis points.

5/ Minimum capital needed to bring all banks to at least zero capilal level. Please note that $T S h$ I million is approximately equal USD 1,000

6/ Minimum capital needed to bring all banks to at least 8 percent CAR. Please note that T Sh 1 miilion is approximately equal USD $1,000$.

7/ With an appreciation by 20 and 30 percent, 20 and 30 percent of loans to most exposed sectors become non-performing, respectively (olher assumptions the same as in direct credit shock). Most exposed

sectors include agriculture, trade, and mantfacturing.

8/ Impact of a reduction of interest charged on outstanding loans, with deposit interest rates unchanged in a one-year period.

$9 /$ Sectoral shocks to credit quality, with 5-60 percent of loans bccoming non-performing (other assumptions the same as in direct credit shock) 
40. Contrary to what might be expected--given that Tanzanian banks lend mostly short-term and given that the few existing medium-term loans have floating interest rate-banks still have a substantial negative gap at short maturities. Demand deposits form the vast majority of deposits and even the existing time deposits have relatively short maturities. Furthermore, several banks hold substantial portfolio of government bonds. The resulting exposure to interest rate risk is substantial for several banks. Two large banks would actually become insolvent or near-insolvent, should all interest rates increase by 700 basis points on a sustained basis. These banks have large branch networks and would probably be able to mitigate the interest rate shock to some extent by delaying the adjustment to some deposit rates without immediately losing deposits, but competition would likely limit longer term viability of this strategy. Also, shifting the cost of interest rate mismanagement to depositors is not optimal, particularly if financial intermediation is to develop in Tanzania. Moreover, the interest rate risk exposure will grow once banks expand their loan portfolios. The BOT therefore needs to develop appropriate reporting and monitoring systems for interest rate risk exposures.

41. Exchange rate risk appears to be properly managed by the banks. The regulatory limit of 20 percent of capital has been breached occasionally, but it is well monitored by the BOT. In any case, the demand for foreign currency denominated loans is rather weak. Even taking into account the secondary impact of exchange rate risk on credit quality, the results suggest that the banking system is able to endure exchange rate shocks rather well, since a 30 percent depreciation would only marginally decrease the system-wide CAR and no bank would get below the 8 percent CAR limit. A 30 percent appreciation would have a higher impact, decreasing the system-wide CAR to below 14 percent and putting one small bank's CAR in the 5-10 percent range, although a relatively small amount of capital would be needed to correct the problem.

42. A different perspective on the sensitivity analysis (Table 6) underlines the resilience of the system to shocks. No bank would become insolvent even with 32 percent of outstanding credit suddenly becoming nonperforming; it would take more than 51 percent of new nonperforming loans to make more than one quarter of the system insolvent. Similarly, the system is resilient to the exchange rate shock, even though the sensitivity to appreciation increases significantly once the shock exceeds 50 percent. Again, the resiliency to interest rate shock appears to be relatively smaller, since a rather plausible shock of over 640 basis points makes a quarter of the system insolvent. 
Table 6. Tanzania: Sensitivity Analysis 1/

\begin{tabular}{lrrr}
\hline & \multicolumn{3}{c}{ Insolvent banks (\% of system assets) } \\
\cline { 3 - 4 } & $0 \%$ & $10 \%$ & $25 \%$ \\
\hline Credit shock (\% of loans becoming non-performing) & $32 \%$ & $35 \%$ & $51 \%$ \\
Interest rate shock (b.p.) 2/ & -540 & +540 & +640 \\
Exchange rate shock - depreciation & $86 \%$ & $100 \%$ & $168 \%$ \\
Exchange rate shock - appreciation & $50 \%$ & $51 \%$ & $59 \%$ \\
\hline 1/ Largest shock that can be survived by all but a given share of the system. Insolvency refers to \\
negative equity. \\
2/ The interest rate shock is the same for both 0 percent and 10 percent because a larger shock \\
makes one large bank (with over 10 percent of assets) insolvent.
\end{tabular}

43. The four hypothetical scenarios combine different shocks in an attempt to describe and assess the key macroeconomic risks. As outlined above, the main macroeconomic risks for the financial sector arise from the structure of the real economy and dependence on large amounts of potentially volatile donor aid flows. The scenarios include a shock to agriculture, a sudden fall of tourism revenues, drop in aid flows combined with a fiscal meltdown, and a sudden surge in aid flows. ${ }^{9}$ Two of the four scenarios, shock to agriculture and drop in foreign aid flows and fiscal meltdown, would have a serious impact on the banking system. In both cases, more than half of the banking system capital would be lost, much of the system would be either insolvent or near insolvent, and substantial resources would be needed to recapitalize the system. The banking system would be able to endure a drop in tourism revenues considerably better, but a substantial number or banks (and assets) would be close to insolvency. On the other hand, the appreciation shock due to higher aid flows would have a rather low impact on the system.

\section{Managing Risks and Addressing Vulnerabilities}

\section{A. Prudential Regulation and Supervision}

44. Banking supervision by the BOT has a well-founded statutory basis. Specific prudential requirements are contained in the Banking and Financial Institutions Act, 1991, and in regulations and circulars issued by the BOT pursuant to that Act. Supervisory responsibilities cover both banks and nonbank financial institutions (limited to those institutions that take in deposits or conduct other customary banking functions). The BOT also licenses and supervises foreign exchange bureaus.

${ }^{9}$ In calibration of the scenarios, no historical shocks offer guidance as the financial system is relatively new and there have not been major shocks in recent years. The scenarios were calibrated in consultation with BOT staff with the aim to identify exceptional but plausible shocks. 
45. Progress has been made in developing the banking supervision framework, and much effort has gone into the development of the supervisory skills and on-site supervision. Reflecting this progress, banking supervision in Tanzania largely complies with many of the Basel Core Principles. Supervisory improvements are, however, required in several key areas to continue maintaining the financial soundness of the banking system. These include capital adequacy requirements, off-site surveillance, on-site examination, loan loss and provisioning requirements, corporate governance, and management of other risks. The BOT has also not yet developed sufficiently effective working relationships with authorities supervising parent banks of subsidiaries that operate in Tanzania (Part II). Transparency of banking supervision does not pose any concerns from the systemic point of view, but requires further strengthening (Part II).

46. A number of provisions in the legislation have the potential to compromise the independence of the BOT on banking supervision matters even though substantial operational independence has already been gained. These include the minister's potential involvement in the licensing and de-licensing process, and the need for the BOT to obtain the minister's consent to place a bank in statutory management. Moreover, a degree of regulatory forbearance in the past, particularly in the case of state-owned banks, suggests that the BOT is not fully immune from political influence. It is therefore suggested that consideration be given to amending the Act in ways that reinforce the BOT's supervisory independence. Greater independence would need to be balanced with greater transparency and accountability in banking supervision.

47. There is no prompt corrective action framework to deal with problem banks and a framework is needed for dealing with situations where banks breach pre-defined risk limits or capital requirements. It should be so designed as to avoid an overly rigid approach to dealing with these situations. The objective should be to create a presumption of specific prompt corrective action, while still affording the BOT some flexibility as to how it implements that corrective action. Internal strategies and procedures for dealing with weak banks and bank failure are also required.

48. Regulation of the private insurance industry follows the Insurance Act, 1996 and is the responsibility of the Insurance Supervision Department (ISD) of the ministry of finance. The ISD is a relatively new organization having come into being at the time when the National Insurance Company's (NIC's) monopoly was ended and private insurance companies were permitted to enter the market. The ISD employs an approach to supervision that is based upon solvency monitoring. Companies must file periodic financial results with ISD using a prescribed form and monitoring is based on the analysis of these returns, supported by on-site inspections. Although still in its infancy, the ISD should work quickly to overcome a number of difficulties it currently faces. Insurance companies have complained that ISD inspections tend to be burdensome and are dedicated only to verification and compliance-checking. It would be preferable if the work of the inspectors was to involve instead risk identification and assessment, focusing on those areas of a company's operations that pose the greatest risks. Companies should also be required to provide an annual actuarial review and the ISD should obtain the services of a qualified actuary to scrutinize the reviews. 
49. The capital market, which is barely five years old, has been fostered by the Capital Markets and Securities Authority (CMSA) which implements the legal and regulatory framework within which the capital market operates. The CMSA supervises the Dar-es-Salaam Stock Exchange (DSE), which is a fledgling self regulatory, not-for-profit organization. The DSE has primary responsibility for supervising trading on its very small, illiquid, open outcry market, ensuring that the six broker and dealer members licensed by the CMSA adhere to its trading, depository, clearing and settlement rules, and monitoring compliance of its listing rules by the five companies listed on the exchange. The CMSA has instituted a regular broker surveillance program whereby it conducts on-site inspections, actively monitors licensees' compliance of the law, and takes action for cause. However, at this stage of the market's development, the CMSA's role is to be seen more as motivator rather than enforcer, educator rather than protector of investors' rights, and central to policy making and standards setting for all aspects of securities market regulation.

50. The BOT has recently been vested with explicit powers for the oversight of the Tanzania payments and securities settlement systems. Its oversight powers encompass all types of systems including large value, and retail payment systems, and private sector operators of any type of payment systems. A National Payment Systems (NPS) oversight team has been set up to strengthen coordination within the BOT among the payments, banking supervision, financial markets, and economic policy functions. The BOT should issue a Board-approved policy stance on payment and securities settlement system oversight, and its role in maintaining financial stability, early detection of distress, or liquidity problems in the financial system. The BOT also needs to coordinate closely with the CMSA in areas of overlapping responsibilities in the area of securities settlement systems. A formal cooperation agreement would also be consistent with Tanzania's regional cooperation initiatives toward integration of stock markets and cross border payments (see also Section IV.B).

\section{Lender-of-last resort (LOLR) and deposit insurance}

51. The BOT acts as LOLR for banks with temporary liquidity problems; the Deposit Insurance Fund (DIF) can also provide liquidity support to banks. The modalities of the LOLR function are ambiguous. It is not clear which of the three BOT standing facilities (i.e., discount window, unsecured overdraft facility, and the seasonal refinancing facility) is the main LOLR facility. In addition, the relationship between the access of banks to the BOT liquidity facilities and the financial assistance through the DIF needs to be made explicit since there is a presumption that the governor in his role as chairman of the DIF can also use his influence through the DIF to authorize liquidity support for any specific financial institution. Given the uncertainties surrounding its liquidity support function and the overall resource constraints it faces, the DIF's functions should be limited to those of a pure pay box organization. Its liquidity support function should be abolished.

\section{A risk also remains that insolvent banks can obtain liquidity support through} the BOT's unsecured overdraft facility available in respect of temporary clearing imbalances. The proposed move toward establishing a Lombard facility, which will allow banks to borrow on demand against government securities, is therefore a welcome step. At 
the time of the introduction of the facility, the BOT should avail of the opportunity to issue a clear statement of its role as the LOLR, its relationship with the DIF, and the operational modalities relating to the LOLR function. There is also a need to establish a closer relationship between the LOLR function of the BOT and the resolution of problem banks. A more formal mechanism is needed for classifying distressed banks based on those with liquidity problems vis-à-vis those that are insolvent or are on the verge of insolvency. Such mechanism should establish clear principles under which emergency support can be provided as well as a transparent channel through which the BOT can explain its actions in this regard while taking into account confidentiality and market sensitivity considerations.

\section{B. Management of Systemic Liquidity and Development of Financial Markets}

\section{Management of systemic liquidity}

53. Monetary growth in Tanzania has consistently exceeded targeted levels. The combination of large foreign inflows (approximately 7 percent of GDP on average over the period 1999-2002), the failure of the BOT to fully sterilize the liquidity effects of these flows, and the lack of suitable lending opportunities has created a large structural excess liquidity in the banking system in Tanzania. ${ }^{10}$ The BOT therefore faces the challenge of how to manage the systemic impact of the existing and prospective increase in foreign inflows in order to preserve the low inflation and high growth environment. The BOT has made recent adjustments in its monetary operations to meet this challenge. However, sterilization polices have often conflicted with exchange rate considerations, and the BOT has come across as being reticent in mopping up excess liquidity through foreign exchange sales. In addition, shallow financial markets, a skewed distribution of liquidity in the banking system, and weak market infrastructure, have also complicated BOT's liquidity management efforts.

54. To enhance the BOT's ability to effectively sterilize the impact of foreign inflows, a sterilization plan needs to be developed, comprising a suitable combination of foreign exchange sales and net treasury bill issuance. The mix of the sale of foreign exchange and treasury bill issuance must be such as to have the least distortion on both the foreign exchange and money markets, that is, not causing excessive nominal appreciation of the exchange rate or a sharp increase in interest rates, but while being effective in sterilizing structural liquidity consistent with the overall monetary program. The decision on the extent to which to rely on either market should take into account the price responsiveness in both markets and their technical features, including the seasonal profile of liquidity.

55. Foreign reserves held by the BOT are presently at comfortable levels (eight months of imports), and the BOT has at its disposal a mix of instruments to conduct open market operations effectively. To manage reserve money, the BOT currently uses

\footnotetext{
${ }^{10}$ Excess liquidity has been on average over 3 percent of broad money between 1999 and end-2002.
} 
reserve requirements, the sale of 91-day liquidity papers, and short-term repurchase operations. Foreign currency operations are also used on occasion. ${ }^{11}$ The BOT's net income and capitalization appear sufficiently strong to sustain a proper sterilization plan.

\section{Two measures are needed to further strengthen BOT's monetary policy} framework as a complement to a sterilization program. The first consists of continuous and more analytical work on modeling money demand and other relevant macroeconomic relationships. The presumption of stability in the money multiplier has underpinned the base money program pursued by the BOT. Over the last two years, however, actual money supply has consistently exceeded its target. But there has been a divergence in the money supply and trend inflation, reflecting, perhaps, a structural change in money demand. More analytical work is needed to determine whether this is indeed the case. Such analytical work should include modeling money demand, and building a time series of money demand and the factors that impact it. In addition, a thorough study of the factors affecting velocity also needs to be carried out (Box 4).

\section{Second, the BOT also needs to make further refinements to its short-term} liquidity forecasting process to improve monetary policy implementation. Monthly, weekly and daily forecasts are produced for the purpose of identifying the necessary policy response to changes in the autonomous supply of liquidity. However, significant forecast errors occur, largely on account of the unavailability of accurate and timely information to forecast government's income and expenditure flows, assets, and liabilities. To improve the liquidity forecasting process, the BOT should, as a first step, start analyzing forecast errors. Then, more fundamental issues may need to be addressed about the data sources and who should forecast each component.

\section{Developing financial markets}

58. A better-developed and smoothly functioning interbank market would help monetary policy implementation. With some banks structurally short of local currency liquidity, and a few others holding the bulk of it, the BOT often finds itself providing liquidity to ease immediate pressure on a few institutions when the macro environment calls for a tightening. Steps by the BOT to develop market infrastructure have not yet borne much fruit. Among needed action is the establishment of a legal basis for repo transactions through the introduction of a master repo agreement, setting up systems that allow for more efficient and safer settlement of high-value operations, and the efficient use of the book entry system to support secondary market transactions.

\footnotetext{
${ }^{11}$ Although available, standing facilities are not currently used as an operative instrument of monetary policy owing to the presence of excess liquidity in the banking system. The reserve requirement, which is currently at 10 percent, has been coming down over the years and the authorities are unwilling to increase it again as a means of sterilizing excess liquidity.
} 


\section{Box 4. Sterilization of Aid Flows}

The scale of aid flows projected for the future represents a significant increase over what has been experienced so far. It should, of course, be noted that net inward Official Development Assistance (ODA) averaged 10 percent of GDP in the 1990s, so the ability of Tanzania to absorb aid flows should not be underestimated. To the extent that aid flows are directly spent on imports without adding to domestic demand, there need be no evident macroeconomic consequences. More generally, if aid money implies an increase in domestic spending, a sustained increase in such flows implies certain other adjustments in equilibrium, as is illustrated even in a model as simple as that of Mundell and Fleming (an alternative, somewhat more neoclassical framework, is in the so-called Dutch disease models such as that of Neary and Corden). These adjustments need to be taken into account in adapting monetary policy to the new equilibrium.

Real interest rates and real income (increases), along with the real exchange rate (appreciation) can all be expected to change in order to achieve the realignment of income, expenditure and net exports needed to clear domestic goods, money, and foreign exchange markets. The size of the equilibrium changes depends in particular on the marginal propensity to import out of increased income, the price elasticity of imports and on the interest sensitivity of money demand. If either or both of the first two are high - which is likely, though precise and reliable estimates do not appear to be readily available for Tanzania - the equilibrium changes will be small. Nevertheless, they will have an impact on the demand for real money balances.

Turning to nominal magnitudes and the role of monetary policy, clearly the goal should be to accomplish the adjustment without any impact on inflation. This implies, for example, that the planned growth path of nominal monetary aggregates including the target for reserve money, should be compatible with the pre-existing intended path of prices and the new equilibrium money demand. In practice, none of these magnitudes will be known with precision. Nevertheless, an intended (target) path for reserve money corresponding to the planned inflation rate, and an expected path of interest rate and exchange rate should be calculated based on the best information available. Then as events unfold, the deviations of actual from expected can be used to feedback into the model underlying the original forecasts in order to revise the parameters. Higher inflation, or a lower than expected interest rate or exchange rate appreciation would signal the need to tighten the reserve money target, and so on. The monetary targets thus need constant attention in case the demand for money and other relevant relationships should prove to be different to what was expected.

\section{The BOT's intervention practices in the foreign exchange interbank market} should be adjusted to aid liquidity management and facilitate the development of the market. The BOT is a dominant player in the market and intervenes regularly to meet mismatches in demand and supply and to smooth exchange rate fluctuations. Over the last four years, however, foreign exchange operations, on a net basis, have led to an injection of domestic liquidity, rather than a withdrawal, in an economy characterized by excess liquidity. Although the BOT denies that it targets the exchange rate, it appears clear that one of the objectives of its intervention has been to maintain competitiveness of the domestic currency. In addition to its adverse effects on liquidity management, the active presence of the BOT in the interbank foreign exchange market acts as a disincentive to the banks to manage and price the risks associated with their foreign exchange positions since they rely on the BOT to absorb significant imbalances in the market. In view of the nature of the market and the seasonality of flows, the BOT may need to intervene, but it should reduce its presence. 
60. While the primary market for treasury bills is well established, the secondary market is inactive. Recent developments in the treasury bond market have raised concerns regarding the functioning of that market. In August 2002, in response to a substantially increased sterilization requirement and the desire to extend the risk-free yield curve, the BOT and the MOF agreed to convert T Sh 120 billion of non-marketable and non-interest bearing debt on the BOT balance sheet into marketable treasury bonds of 5-, 7-, and 10-year maturities. The initial auctions were successful with more than adequate bid cover for the amounts offered, but in March 2003 the appetite for longer duration securities suddenly dissipated with auctions no longer attracting a sufficient volume of bids. ${ }^{12}$ These developments affect the development of the treasury bond market and for price discovery at the longer-term end of the yield curve. The strategy for primary market issuance (maturities, volumes, and timing) needs to be revisited. Critical to this process is soliciting of market intentions and portfolio strategies of the major investors. The authorities should actively consider a more gradual approach to lengthening the yield curve, perhaps first focusing on establishing a five-year liquid benchmark, before moving to longer periods. Failure to implement these measures will mean that the liquidity premium will remain high, resulting in higher than necessary sterilization costs.

\section{Payment and settlement systems}

61. A gradual approach to improve Tanzania's wholesale payment systems has been implemented since 1996, when the NPS modernization project was launched. It encompasses an electronic clearing house (launched in March 2002); an electronic funds transfer system (expected to go live in 2003); and the Tanzania interbank settlement systems offering RTGS facilities (April 2004). A new government securities depository system was launched in July 2002 for government securities (treasury bonds and treasury bills) issued by the BOT. A central depository system is also operated by the stock exchange to allow book entry processing for corporate securities. The BOT's NPS modernization project appears overall to be a consistent initiative to develop gradually the payment systems infrastructure.

62. There are a number of risks to the conduct of effective monetary policy implementation stemming from the settlement process of the monetary policy operations of the BOT. These consist of the following: (i) insufficient protection of the electronic clearing house system against settlement risks of its participants; (ii) a lack of definition of irrevocability of payment orders and of finality of payments to support effective legal framework for payment systems; and (iii) inadequate arrangements for delivery versus payment (DvP) for both government and corporate securities. Furthermore, DvP is not achieved in BOT's repurchase transactions and foreign exchange interventions. Operational reliability could become a source of concern in particular after the launch of the interbank settlement system. Several steps are required to address these risks. These include: (i) setting

\footnotetext{
${ }^{12}$ It is believed that the appetite for longer duration securities dissipated because of the issuance strategy employed by the BOT in terms of maturities, volumes and timing.
} 
up a safe custodial framework allowing the government securities depository to move to an indirect holding structure; (ii) upgrading the settlement process for nonbank institutions;

(iii) ensuring DvP settlement of secondary market trades on treasury bills and treasury bonds;

(iv) enforcing adequate risks control measures to protect the securities settlement system against the risk of default of clearing banks; and (v) introduction of DvP (PvP) in BOT's monetary operations.

\section{Transparency of monetary policy}

63. The BOT displays a satisfactory degree of transparency in its formulation and implementation of monetary policy. The objectives and responsibilities of the BOT, its relationship with the government, and the broad modalities of accountability are defined in the Bank of Tanzania Act, 1995. The law is supplemented by regulations that define the procedures and practices governing monetary policy instruments and the framework within which monetary policy is to be implemented. Through its publication program, the BOT endeavors to bring its monetary policy objectives and decisions to the attention of market participants and the public at large. It also publishes the Monetary Policy Statement (MPS), which is tabled before parliament. Several areas remain, however, in which the BOT needs to improve further its monetary policy transparency and accountability practices. These include clarification and publication of its actual objectives, specification of criteria for potential removal of the governor, further improvement of communication with market participants, shortening the considerable delays of many publications, and formalization and disclosure of coordination with the ministry of finance.

\section{Improving the EFFECTIVENESS AND REACH OF THE Financial SECTOR}

\section{The Tanzanian financial sector performs only a very limited role in the} economy, even by Sub-Saharan African standards. Improving the effectiveness and reach of the sector must therefore be a matter of priority for the authorities if the sector is to perform its expected role in promoting the growth of the economy. Among the urgently needed actions are strengthening market foundations, direct government action to strengthen the provision of financial services, and measures to increase the supply of institutional equity and term finance.

\section{A. Strengthening Market Foundations}

\section{It is well recognized in Tanzania that legal judicial and informational} infrastructures are key to sustaining the progress of financial sector reforms. As such, the authorities have recently introduced wide-ranging reforms in these areas, including the Land Act 1999 and the Companies Act 2002. They both contain important advances, but both are also flawed in important respects with implications for the availability of mortgage-based finance. Because of bankers' caution, as well as the collateralization requirements of the BOT, mortgages remain important in Tanzanian banking, even where the main assurance of creditworthiness is the expected cash-flow of the business. The Land Act 1999 altered the 
position with regard to mortgages in several important ways, which impede the development of mortgage lending. It appears, however, that most of the main problems are technical and can be resolved without compromising other (social) goals. These would include a reduction in statutory delays and elimination of the prohibition on sale of unimproved land and replacing it by taxation of capital gains to achieve the same purpose. ${ }^{13}$

\section{Judicial and court reform is one of the basic priorities to which increasing} attention is being paid. However, comparatively little progress has been made, with training and facilities remaining items in need of special attention. The new commercial court was at first quite effective in reducing delays (perhaps contributing to Tanzania's relatively good performance by international comparison) and justified the additional court costs imposed on litigants. But the number of judges in the court (three) has been insufficient for the volume of cases, with the result of a renewed accumulation of unresolved cases. Furthermore, there is no commercial division in the court of appeals, so delays are longer at that stage. The recent raising of the threshold to $T$ Sh 200 million for the value of individual claims that must be settled through the regional courts should reduce this backlog, although at the cost of limiting the value of the commercial court.

\section{Several remediable reasons continue to restrain the development of leasing in}

Tanzania. One is uncertainty in the definition of financial institutions in the law, which may make a leasing company subject to prudential regulation of the BOT. This matter should be clarified, as there is no reason to apply prudential supervision to a leasing company which is not financed by deposits from the general public. Another removable barrier may be the 10 percent ceiling on a bank's holding of fixed assets, which might appear to represent a barrier to a bank undertaking leasing arrangements if the leased-out assets were treated as being subject to this ceiling. Perhaps less easy to correct is the practice of some courts to entertain injunction by borrowers at the time of repossession where the lessee has paid more than 50 percent of the value of the property in question. This is despite the fact that the law seems to be clear on the point that ownership remains with the lender. Evidently such injunctions can result in delay and cost for lenders especially since the property is movable.

\section{Smooth functioning of so many aspects of credit and finance depend on efficient} and comprehensive registries: land registries, company registries, registries of mortgage and chattel interests. All of these exist in Tanzania but their functioning and efficiency need to be improved. Most directly relevant of such entities is the credit registry or credit bureau, which Tanzania does not have. Considerable attention has been focused in recent years on the potential advantages of such a registry for improving the information basis on which credit decisions can be made. Progress toward establishing a registry has been

\footnotetext{
${ }^{13}$ Meanwhile, it seems unduly restrictive to require any loan above 5 percent of a bank's capital to be over-collateralized at 125 percent of value. A relaxation of this rule would go some way to easing the availability of credit for those unable to easily produce sufficient acceptable collateral.
} 
hampered by at least two misconceptions. One is that a registry necessarily needs the prior establishment of a national identity number. The other is that the leading banks will be enthusiastic promoters of the idea, whereas they tend to resist the sharing of information that is involved. It is clear that the initiative must now be reassumed by the authorities (BOT) with a view to establishing a very simple but compulsory system of credit reporting by all licensed lenders.

69. Other key elements of the financial infrastructure, at least for the larger companies, are the arrangements for accounting and auditing and for corporate governance. By providing information to and protection for lenders, minority shareholders and other stakeholders, these underpin the confidence with which financial services and funds can be extended to companies. Accounting and auditing standards in Tanzania at present are consistent with international standards but adapted to meet local conditions. Tanzania is proposing to adopt international accounting standards and international auditing standards effective as of July 1, 2004. Although the Companies Act 2002, soon to be implemented, should succeed in modernizing the regulation of company accounting and audit practices in Tanzania, at least two major concerns remain. One relates to the power conferred on the minister of industry and trade to interfere under certain circumstances in the preparation of a company's audited annual accounts; the other to the requirement that a company's financial statements give a true and fair view of its state of affairs as at the end of its accounting period, apparently even if this involves a deviation from the accounting standards. This apparent override of IAS carries significant risks.

70. The BOT needs to ensure that public confidence in the financial system is not endangered by a retail payment infrastructure that would be impractical or unsafe for users. The BOT should undertake a comprehensive and a forward looking study of the retail payment infrastructure, pursuant to its new payment system oversight role. Further important steps include the following: (i) careful review of the conditions under which the ownership of the electronic clearing house is to be transferred to commercial banks; (ii) the BOT, in cooperation with commercial banks, should clearly define and disclose its strategy toward the development of retail payment infrastructure; and (iii) banks should establish interoperability of card-based networks, in order to broaden the use of payments cards.

\section{B. Provision of Financial Services}

71. Among its possible direct actions, it is most important that the government develop and execute an appropriate policy in regard to each of the banking institutions it still owns. Four banking institutions remain in public ownership. These are NMB, TPB, TIB, and the PBZ. ${ }^{14} \mathrm{NMB}$ has a stable, large and steadily growing deposit base, thanks to its wide branch network and a very liquid balance sheet. Its management, however, is still

\footnotetext{
${ }^{14} \mathrm{~A}$ fifth banking institution, the National Bureau de Change, seems to have no distinctive social role and should be liquidated if no buyer can be found.
} 
financed by donors and it has insufficient capital to significantly expand its small lending operations. TPB and TIB operate with more restricted nonbank financial institution licenses. TPB has an agency relationship with the Post Office and resembles a narrow bank in that its main business has been to offer passbook savings and postal transfers. TIB has only one branch, few depositors and virtually no long-term financial resources. PBZ is insolvent and operates under a recently signed MOU. ${ }^{15}$

72. Privatization of the NMB should not be delayed. There was a false start earlier this year when a parliamentary committee rejected detailed proposals for the terms of offer of sale. This effort needs to be recast and relaunched. In order to be sure of attracting a strong buyer, a solid majority percentage of the bank should be on offer. Acquisition by a bank with an already large share of the market would need to be scrutinized from the perspective of anti-competitive practices. If one sets aside those whose chief goal is either access to the liquid assets, or who wish to suppress competition from NMB for their own banking interests, the highest suitable bidder is likely to be one that fully recognizes the franchise value of the branch network and of the (retail and payments-focused) business model which the bank has developed. ${ }^{16}$

73. TPB and TIB require substantial redirection. The franchise of TPB is clearly not as strong as that of NMB. Its postal agency could easily be transferred to another bank. The investment in systems and training that would be required to allow it to expand its lending business and improve the quality of services provided to depositors may be too great to be justified at present. Instead of trying to compete in the somewhat crowded urban market for micro-loans, TPB might find a more socially and financially profitable role by confining its lending more to the relatively stronger NGO MFIs and large microfinance companies. In any event, a further significant expansion in the TPB's loan portfolio at present would not seem advisable, and it should be transformed into a narrow bank.

74. The authorities' objectives for the TIB also need to be determined as soon as possible. It is hard to see the TIB as the nucleus of an effective development bank, whether in private or public ownership. It may be that the institutional capacity for investment banking at TIB can best be employed through a takeover by an existing bank, as the commercial banking end of the business has little franchise value. Expressions of interest should soon be sought from other market participants for its acquisition in total or piecemeal.

\footnotetext{
${ }^{15}$ The proposed strategy is to sell its franchise to a reputable private bank so that it can resume normal commercial banking activities in Zanzibar on a commercial basis.

${ }^{16}$ A privatized $\mathrm{NMB}$ may be able to exploit local monopoly power, for example, in charges made for government payments to remote areas, so coordination with the future strategy for $\mathrm{TPB}$ - the only potential competitor for $\mathrm{NMB}$ in this area-is necessary.
} 
75. The limited reach and efficiency of the financial system have generated calls for more proactive measures by the government. These include potential requirements on existing financial institutions to set aside a portion of their resources for lending to special categories or regions, or to establish presumably unprofitable branches in rural areas as the price of being permitted to expand branch network in the cities, and creation of development banks. Given the at best mixed record of such initiatives in other countries and the risk that such initiatives may be misunderstood by the financial sector as heralding a reversal of policy and the potential for interventionism in the financial sector-that could upset the tentative improvements observed recently-any plans for such initiatives should be set aside.

76. In microfinance, the thrust of the new legislation enacted earlier this year places emphasis on the larger SACCOs. It appears to foresee a growth in these cooperatives so that they would become licensed microfinance companies (MFC) subject to more rigorous prudential inspection, along perhaps with a handful of the largest NGOs. The move toward a more systematic and thorough regulatory regime for those few institutions taking more than T Sh 1 billion in deposits is very welcome. However, to the extent that only small institutions can reach remote rural areas in the current state of Tanzania's transport infrastructure, it is arguable that they should not be suppressed by excessive regulation. Instead, the authorities should consider ways of encouraging the development and strengthening of umbrella organizations, and of greater reliance by these MFIs on local banks rather than external donors for loanable funds. Regulations pursuant to the new legal framework for microfinance need to establish a flexible framework, taking into account the broad diversity of the SACCOs. Also, the authorities should consider establishing a developmental agency for cooperative financial institutions, which would focus donor support on capacity building and financial infrastructure.

\section{Institutional Equity and Term Finance}

77. Improving the flow of long-term funds to private borrowers requires a source of funding as well as a financial technology for ensuring that the funds are well used. Tanzania enjoys an exceptionally favorable potential position in this regard in view of the growing investable resources of the two major publicly controlled pensions funds. Realizing this potential, as well as ensuring the healthy growth of the insurance industry, in view of its own risk-pooling function as well as a potential long-term investor, is of critical importance.

78. The insolvent state-owned NIC is a major obstacle to restoration of public confidence in the insurance industry. Until 1998, this company had a monopoly, and it continues to be the largest insurer, though with a rapidly diminishing market share (30 percent of general insurance premiums collected in 2001, 22 percent in 2002). The main reason for this rapid decline is the extremely poor record of this insolvent though government guaranteed company in paying non-life claims. Despite some declared international investor interest, the non-life business seems unlikely to be attractive to any investor. Unless this is soon proved otherwise, there would appear to be little alternative to liquidation or running off 
the business; either course would entail sizable and early budgetary implications.

Nevertheless, the restoration of public confidence in the insurance industry will only begin once the case of NIC is settled.

79. As regards investment policy of insurance companies, the current regime is rather restrictive, requiring the majority of investments to be placed in government securities or bank deposits. Very little leeway is given for investing in equity markets or in corporate securities and no funds can be invested outside Tanzania. In the interests of a progressive increase in the investment activity of the insurance industry in private long-term finance, relaxation of these rules should be considered.

80. Pension fund assets appear excessively liquid and are heavily weighted to government securities. The governing legislation does not impose any restrictions on their investment practices. However, each fund has adopted its own investment policy. The asset portfolios of two largest funds at the end of 2002 were heavily weighted in government paper, cash, and short-term investments. Pension obligations are long-term by nature, but the portfolios are very liquid for funds of this kind. While prudence would dictate that some proportion of the portfolios should be held in government securities, the amounts shown are exceptional and the portfolios have excess liquidity in light of its operational requirements. The funds would be well disposed to invest in equity markets and in securitized loans or bank-guaranteed bonds when appropriate opportunities were provided to them, and this would be a much more transparent and productive use of the funds than making special loans on an ad hoc basis to various government-sponsored projects.

\section{The overall tax system does not appear to limit financial sector development at}

present. The tax authorities, however, are somewhat restrictive and do not allow a defaulted loan to be deducted until a very late stage. This caution is understandable in view of the major fiscal costs of bank failure in recent years, and it may be too early to expect a relaxation of this position, though it should come in due course. Similarly, tax treatment of pensions is rather severe by international standards: contributions, fund income and the pension itself are all taxed. A medium-term goal could be to remove taxation at the pension payment stage. Given that the pension arrangements concerned are compulsory, the incentive effects are likely to be small. On the other hand, the tax treatment of capital gains on new share issues are overly generous, and this distortion is one that can be removed without damaging the budget. 


\title{
Part II. Observance of Financial Sector Standards And Codes: Summary ASSESSMENTS
}

\begin{abstract}
This part contains summary assessment of Tanzania's adherence to the Basel Core Principles. The assessment was carried out as part of the FSAP. It has helped to identify the extent to which the regulatory and supervisory framework in Tanzania is adequate to address the potential risks in the banking system, as well as the strength of the underlying regulatory governance practices. The assessments have provided the basis for making recommendations for further strengthening of the institutional, legislative, and regulatory aspects of the banking system stability framework. The summary is based on the detailed assessments undertaken as part of the FSAP by Shyamala Gopinath (International Monetary Fund) and Geoffrey Mortlock (Reserve Bank of New Zealand). The assessment was preceded by a self-assessment undertaken by the BOT, which was evaluated during the FSAP by focusing on actual practices and verified through discussions with the authorities, market participants, industry associations, and self regulatory organizations. The findings were cross checked with quantitative information available through the stress test, and relevant laws and regulations. The authorities have acknowledged that the process of self-assessment and the FSAP assessment have helped to identify some key risk factors which need to be addressed, while enhancing the transparency of banking supervision.
\end{abstract}

\section{Basel Core Principles for Effective Banking Supervision}

\section{A. General ${ }^{17}$}

82. The assessment of compliance with the Basel Core Principles for Effective Banking Supervision was based on the Basel Committee's Methodology for the Assessment of the Core Principles. Compliance was assessed against the "essential" criteria. The assessors applied the discretion provided by the Methodology to undertake an assessment taking into account specific features in Tanzania affecting the financial system. The BOT cooperated fully with the assessors and provided all the necessary clarifications and supporting documents. As prescribed in the Methodology, the assessment was based on the supervisory system and practices as in place at the time of the assessment (October 2002).

83. The sole banking supervision authority in Tanzania is the BOT. The responsibility for licensing and supervising banks and other financial institutions conducting banking business is vested with the Directorate of Banking Supervision (DBS). The BOT also has responsibility for intervening in problem banks and nonbank financial institutions. In the recent period, considerable progress has been made by the BOT in developing the banking supervision framework. However, further improvements are needed to the banking supervision arrangements, requiring amendments to the law and regulations, development of banking supervision policy, capacity-building and risk based supervisory practices.

\footnotetext{
${ }^{17}$ See Part I of the FSSA report for more details on the industry structure and macro prudential setting.
} 
84. Transparency of banking supervision does not pose any concerns from the systemic point of view. ${ }^{18}$ The main documents relating to banking supervision, laws and BOT's regulations and circulars, are publicly available. The objectives of banking supervision, activities of the DBS, policy developments, and some other relevant information are set out in an annual report of the DBS. Neither the law nor the annual report, however, are sufficiently specific about the objectives of banking supervision and performance benchmarks. The BOT consults with the Tanzania Banking Association and auditors on proposed banking supervision changes, but there is scope for improvement. The BOT maintains close working relationship with other domestic supervisory agencies and with such agencies from other countries in the region, but without any formal agreements.

85. The transparency of banking supervision needs improvement in five areas. First, objectives, performance benchmarks and other accountability instruments of banking supervision should be more clearly specified and published. Second, the DBS annual report should be developed to include an assessment the extent to which the objectives were achieved. Third, the DBS section of the BOT website should be developed to include all relevant public documents. Fourth, formal MOUs with domestic and foreign supervisory agencies should be established. Fifth, the consultation process with banks and other interest parties should be strengthened.

\section{B. General Preconditions for Effective Banking Supervision}

86. In recent years, the banking system has benefited from the Tanzanian economy performing well, displaying relatively strong per capita GDP growth and only moderate inflation. There has been progress in developing the financial infrastructure supporting the financial system. However, several macroeconomic factors continue to present potential threats to banking system stability, including susceptibility to fluctuations in aid flows, failing commodity prices for Tanzania's main exports, drought, and the fragility of the tourist market.

87. In several respects, sound accounting practices are in place. The current set of national accounting standards is closely based on IAS, and the auditing guidelines are modeled on international guidelines. Tanzania plans to fully harmonize its accounting standards with IAS as of mid-2004. The legal system is being developed. Attention, however, needs to be given to the Land Act to provide for a system that enables good title to be given to land. It is also necessary for the judicial system to be resourced to enable it to efficiently process commercial litigation, such as litigation relating to nonperforming loans and the enforcement of legal contracts. Information infrastructure also needs further development, including the establishment of a credit registry.

\footnotetext{
${ }^{18}$ This area was assessed based on the IMF's MFP Transparency Code. No detailed assessment was carried out, however.
} 
88. The new Tanzanian Companies Act (scheduled to come into force in late-2003), will strengthen some aspects of the corporate governance framework, particularly in respect of directors' duties. However, the new Act does not provide for penalties where directors' duties have been breached; nor does it provide for the disqualification of directors where they fail to comply with their statutory duties. More generally, the authorities need to review international best practice in the area of corporate governance applicable to financial institutions, with a view to further strengthening the corporate governance environment in Tanzania.

\section{Main Findings}

89. Objectives, Autonomy, Powers, and Resources (CP 1). In most respects, the BOT has satisfactory independence, powers and resources to perform the banking supervision tasks effectively. It has made considerable progress in building credibility as a supervisory authority. However, some elements of the legal framework have the potential to compromise the BOT's independence, including the potential role of the minister of finance in the licensing of banks and the need to obtain the minister's approval for placing banks in statutory management. The objectives of the banking supervision arrangements are not clearly specified in the law or in other publications. And the BOT's powers to share confidential information with other supervisory agencies is not sufficiently clear.

90. Licensing and Structure (CPs 2-5). The legal framework relating to the permissible activities of banks and placing constraints on the ability to use the word "bank" for business purposes is generally sound. However, it would be desirable to clarify and update the definition of "bank" and "banking business" in the law. The BOT's legal framework, policies and practices for licensing and de-licensing a bank (and some types of nonbank financial institutions) are generally satisfactory. It would be desirable if the law could be amended to reduce the scope for the minister of finance to interfere in the decision to license or delicense a bank.

91. The assessors have suggested that BOT develop a policy framework on ownership concentration in the banking system, both in terms of industry dominance and country risk. It is also suggested that the BOT be more explicit and transparent concerning the criteria of significance in determining whether to approve a change in bank ownership. Some clarification of the law and regulations on a bank's ability to acquire another financial institution (including a foreign institution) or to acquire an equity interest in an entity not associated with banking would be desirable; the existing law is somewhat ambiguous in places.

92. Prudential Regulations and Requirements (CPs 6-15). The BOT's prudential regulations and requirements are generally sound but there are a few aspects that need to be strengthened and a few others where new regulations will need to be promulgated. The minimum capital requirements for banks are in line with the Basel Capital Accord and the 
Act has been amended to increase it to 10 percent. However, the capital adequacy ratio does not cover market risks. Moreover, it is applied uniformly to all banks and is not based on the risk profile of the institution.

93. The BOT's regulations on credit policies, asset classification and provisioning are generally sound and largely consistent with the BCP. However, some aspects of the BOT's large exposure policy would benefit from review. The BOT should consider treating any exposure above 10 percent of a bank's capital as a large exposure for the purpose of applying the aggregate limit on large exposures and review the aggregate limit on large exposures which is set at a low level and excessively constrains banks' ability to lend. In the case of banks' placement of funds with the overseas banks (including related parties in some cases), the current limits would allow very large exposures relative to a bank's capital.

94. The BOT has issued detailed regulations on connected lending. A meaningful element not included is the authority of the supervisor to make a conclusive judgment on the existence of a connected party or the relationship between particular parties. These loans are not deducted from capital and there are no specific requirements for collateralization, although in general, loans are required to be collateralized. There are no regulations on country risk and given the currently limited international activity, this does not severely undermine bank soundness in Tanzania at present.

95. Except for regulations on foreign exchange risk positions, the BOT does not assess whether banks have in place systems that accurately measure, monitor and adequately control market risks nor are there requirements to hold capital against market risks. BOT should issue regulations which will specify the minimum requirements for banks' market risk management systems.

96. Methods of Ongoing Supervision (CPs16-20). The BOT has developed a reasonably comprehensive on-site and off-site supervisory framework. They collect most of the relevant prudential information from banks and conduct on-site examinations of all supervised institutions on an annual basis. It is essential for the BOT to strengthen its capacity to assess the information being collected from banks, to focus on the most salient risk elements in that information, and to analyze the information perceptively, including by use of peer group analysis, stress testing, analysis of early warning signals, and broader systemic analysis (including through macro-prudential indicators). Greater reporting of the results of that analysis to the governor and Board, focusing mostly on risk assessment, would also be desirable.

97. The BOT maintains a relatively comprehensive on-site examination process, using its own staff. Much effort has been made to strengthen its capacity in this area and the BOT is developing increasing skill and experience in the assessment of banks. However, the examination process tends to be excessively focused on compliance assessment, with insufficient attention being given to assessing the risks of banks and their capacity to manage those risks. 
98. Information Requirement (CP 21). Banks are required by the BOT to prepare their annual financial statements in accordance with the accounting standards approved by the National Board of Accountants and Auditors. These statements require BOT approval. The BOT requires banks to appoint an auditor from a list of auditors approved by the BOT. In addition, banks are required to publish quarterly disclosures on their financial statements. The assessors recommend that the BOT strengthen the disclosure requirements for banks. It is also suggested that the BOT hold regular trilateral meetings with auditors and develop a closer working relationship with the NBAA.

99. Formal Powers of Supervisors-Remedial Measures (CP 22). The BOT has a range of measures to respond to bank distress events and to pursue remedial measures. However, there are deficiencies in the existing framework, both in respect of the law and the BOT's capacity to respond to distress events. The requirement for the approval of the minister for taking possession of a bank or financial institution in distress potentially undermines the independence of the supervisor and there may be explicit or implicit pressure on the supervisor to postpone measures. It is suggested that consideration be given to amending the law to modify the provision requiring approval of the minister. The BOT should consider introducing the concept of prompt corrective action and introduce automatic rules for preagreed acceptable supervisory actions when a trigger is breached. Beyond this, it is suggested that the BOT develop internal strategies and procedures for dealing with weak banks by preparing a contingency plan that would encompass a range of scenarios.

100. Cross-Border Banking (CPs 23-25). At present, none of the banks domiciled in Tanzania have foreign operations. Therefore, CPS 23 and 24 do not currently apply to Tanzania. However, given the possibility that banks in Tanzania might wish to establish a foreign branch or subsidiary in the future, it would be desirable for the BOT to develop its thinking as to the policy, supervisory practices and the relationship desired with the foreign host supervisor. The BOT supervises the subsidiaries of foreign banks on much the same basis as banks that are domestically owned and therefore complies with this element of the principle. However, the BOT has little contact with parent supervisors and it would appear to be constrained in its ability to share information with them. These are matters that need to be addressed, including the legal capacity to share bank-specific information, the need to build closer working relationships with the parent supervisors, and also the need to reach agreement (preferably documented in MOUs) on the division of responsibility between the parent supervisors and the BOT. 


\section{Table 1. Main Recommended Actions to Improve Compliance with the Basel Core Principles}

\begin{tabular}{|c|c|}
\hline Reference Principle & Recommended Action \\
\hline $\begin{array}{l}\text { CP } 1 \text {-objectives, Autonomy, Powers } \\
\text { and Resources }\end{array}$ & $\begin{array}{l}\text { Specify the objectives for banking supervision and take steps to strengthen BOT's } \\
\text { supervisory independence. Develop capacity-building programs to further enhance } \\
\text { the BOT's supervisory skills, and strengthen the legal protection for the BOT and } \\
\text { its staff. }\end{array}$ \\
\hline CP 5-Investment Criteria & $\begin{array}{l}\text { Clarify the law regarding the BOT's powers to approve a bank's acquisitions of } \\
\text { financial institutions and other entities, and further develop the criteria for assessing } \\
\text { acquisition proposals. }\end{array}$ \\
\hline CP 6-Capital Adequacy & $\begin{array}{l}\text { Adopt the Basel framework for market risks. Based on risk factors, consider higher } \\
\text { capital ratios for banks. }\end{array}$ \\
\hline CP 9-Large Exposure Limits & $\begin{array}{l}\text { Use } 10 \text { percent threshold for measuring aggregate large exposures and consider } \\
\text { increasing aggregate large exposure limit. Limit large exposures to } 25 \text { percent of } \\
\text { capital inclusive of secured and unsecured credits, and introduce limit on inter-bank } \\
\text { exposures based on bank capital. }\end{array}$ \\
\hline CP 10 - Connected Lending & $\begin{array}{l}\text { Ensure that all interbank lending to connected parties is subject to a connected } \\
\text { lending limit; amend law to provide discretion to BOT to make judgments about the } \\
\text { existence of connections between the bank and other parties, require full } \\
\text { collateralization or deduction of unsecured loans from capital; and review single } \\
\text { borrower limit at } 25 \text { percent of core capital for connected loans. }\end{array}$ \\
\hline CP 11-Country Risk & $\begin{array}{l}\text { Introduce a reporting requirement for country risk and apply a limit on country } \\
\text { exposures. }\end{array}$ \\
\hline CP 12 -Market Risks & $\begin{array}{l}\text { Require banks to calculate net open position as per Basel norms and maintain } \\
\text { capital charge on net open foreign exchange positions. Promulgate comprehensive } \\
\text { market risk policics, particularly for interest rate risk. }\end{array}$ \\
\hline CP 13-Other Risks & $\begin{array}{l}\text { Develop more comprehensive guidelines for banks on liquidity risk, Herstatt risk, } \\
\text { operational risks, business continuity risk, payment system-related risks and include } \\
\text { these in on-site examinations, and, over time, develop capital adequacy } \\
\text { requirements as contemplated in Basel II. }\end{array}$ \\
\hline CP 14 Tnternal Control and & $\begin{array}{l}\text { Develop guidelines on internal controls and internal audit, and on corporate } \\
\text { governance and the responsibilities of bank directors. }\end{array}$ \\
\hline $\begin{array}{l}\mathrm{CP} 16-\mathrm{On}-\text { Site and Off-Site } \\
\text { Supervision }\end{array}$ & $\begin{array}{l}\text { Focus examinations on more comprehensive assessment of banks' risks and risk } \\
\text { management capacity. Over time move to risk based supervision, adopt a rating } \\
\text { system (such as CAMELS). Use stress testing regularly, adopting the framework } \\
\text { provided by the FSAP mission. }\end{array}$ \\
\hline CP 17-Bank Management Contact & $\begin{array}{l}\text { Meet periodically with bank directors and management to discuss higher level risk } \\
\text { and strategic issues, meet with parent banks occasionally to discuss parent banking } \\
\text { group issues and parent supervision of their bank in Tanzania. }\end{array}$ \\
\hline CP 18 Off-Site Supe & $\begin{array}{l}\text { Review, simplify, and consolidate prudential returns where possible, develop more } \\
\text { robust analysis of banks' off-site returns. }\end{array}$ \\
\hline $\mathrm{CP} 22$-Remedial Measures & $\begin{array}{l}\text { Develop prompt corrective action framework, develop strategies and capacity for } \\
\text { responding to a range of bank distress and failure situations, improve coordination } \\
\text { with the DIF. }\end{array}$ \\
\hline $\begin{array}{l}\mathrm{CP} 25 \text { - Supervision OV } \\
\text { Banks' Establishments }\end{array}$ & $\begin{array}{l}\text { Develop closer relationships with home supervisory authorities and implement } \\
\text { MOUs. }\end{array}$ \\
\hline
\end{tabular}




\section{Authorities' response}

101. The authorities had an opportunity to review and discuss the BCP assessment report with the FSAP assessors. Overall, they indicated that the assessment was fair. Certain clarifications of fact were provided which were accepted. The Tanzanian authorities have recognized the continuing need to strengthen banking supervision and move towards a risk based system of supervision, and have indicated the need for technical assistance support in the future. As regards the substitutive finding relating to the DIF, the authorities were of the view that its liquidity support function is distinguished from the BOT's lender-of-last resort facilities and that it may not be necessary to abolish it; they disagreed with the mission's view that the DIF's liquidity support was misused in the only recent case of payout from the DIF, and argued that it was a special case. 